\title{
Åldrande och olja. Norsk pensionspolitik i internationell belysning
}

\author{
Urban Lundberg
}

SAMMANDRAG: På ytan faller den norska pensionsreformen från 2009 in i ett internationellt mönster där industrialiserade länder över hela västvärlden anpassar sina välfärdssystem till en tvingande postindustriell problemvärld. Samtidigt är denna normalitet den norska reformens mest besynnerliga drag. Norge är alltjämt ett av världens rikaste länder. Under samma period som pensionsreformen förbereddes och beslutades växte oljeintäkterna lavinartat. Urban Lundbergs artikel tar fasta på denna synbara paradox och visar hur norsk pensionspolitik måste förstås mot bakgrund av hur det dubbla trycket från globalisering och demografi, som i olika grad plågar alla andra jämförbara länder, i Norge genomgående filtreras genom en ännu större fråga om det mest ansvarsfulla sättet att förvalta en ändlig naturresurs. För att ytterligare framhäva den norska pensionsreformens unika särdrag placeras den in i en nordisk kontext där det mer välkända svenska exemplet ges avgörande betydelse.

NYCKELORD: pensionsreform; Norge; normpolitik; olja; överflödsparadoxen.

PUBLICERINGSHISTORIK: Originalpublicering.

URBAN LUNDBERG är docent i historia vid Stockholms universitet.

E-POSTADRESS: urban.lundberg@historia.su.se

FÖRSLAG PÅ KÄLLANGIVELSE:

Lundberg, Urban (2015) "Åldrande och olja. Norsk pensionspolitik i internationell belysning", i Arkiv. Tidskrift för sambällsanalys, nr 4, s. 7-67.

DoI: http://dx.doi.org/IO.I3068/2000-62I7.4.I

(C) Urban Lundberg/Arkiv förlag \& tidskrift 20I5 (publicerad I9 oktober 20I5)

Artikeln distribueras enligt en upphovsrättslicens från Creative Commons:

Erkännande-Ickekommersiell-IngaBearbetningar 3.0 Unported, som medger fri ickekommersiell användning och spridning i oförändrat skick så länge källan anges. 
Arkiv. Tidskrift för samhällsanalys är en sakkunniggranskad vetenskaplig tidskrift för samhällsvetenskap och historia. Samtliga artiklar publiceras fritt tillgängliga på:

www.tidskriftenarkiv.se

(beständig länk, DoI: http://dx.doi.org/IO.I3068/2000-62I7)

Den här artikeln finns tillgänglig i följande format:

PDF \& HTML: via beständig länk, DOI: http://dx.doi.org/IO.I3068/2000-62I7.4.I EPUB: ingår i e-boksutgåva av numret, ISBN: 978 9I 79242725

TRYCK: ingår i bokutgåva av numret, ISBN: 978 9I 79242732

Grafisk utformning och sidnumrering är identisk i pdf och tryck.

Samtliga artiklar i nr 4 (2015) nås via beständig länk, DOI: http://dx.doi.org/IO.I3068/2000-6217.4

Arkiv. Tidskrift för sambällsanalys ISSN: 2000-62I7 (för elektronisk resurs)

ISSN: 2000-6225 (för tryckta nummer)

ges ut av

Stiftelsen Arkiv för främjande och spridning av samhällsvetenskaplig och historisk forskning

genom

Arkiv förlag \& tidskrift

Box 1559

SE-22I OI Lund

BESÖк: L Gråbrödersg $3 \mathrm{c}$, ipg

TEL: O46-I3 3920

ARKIV FÖRLAG: arkiv@arkiv.nu·www.arkiv.nu

TIDSKRIFTEN ARKIV: red@tidskriftenarkiv.se · www.tidskriftenarkiv.se

ANSVARIg UTGIVARE \& CHEFREDAKTÖR: Sven Hort

ADMINistrativ RedAKTÖr: David Lindberg

RedAKtörer: Paavo Bergman, Lisa Kings, Zhanna Kravchenko 


\section{Åldrande och olja. \\ Norsk pensionspolitik \\ $\mathrm{i}$ internationell belysning}

\section{URBAN LUNDBERG}

Det börjar bli sent i de europeiska välfärdsstaterna. Efterkrigstidens ideologiska uppgörelser har ebbat ut och 2000-talets moderniseringsagenda, där anpassningen till trängre omständigheter antog visionära drag bland Europas eliter, har övergått i finansiella kriser och smygande oro över vad som väntar härnäst (Streeck 20I3). Handlingsutrymmet verkar begränsat. Inte utan inre konvulsioner har de flesta länder redan reformerat sina välfärdsstater i linje med en postindustriell problemvärld av jämställdhet, individualisering, flexibilitet, åldrande, global konkurrens, migrationsströmmar, industriell tillbakagång och expanderande tjänstesektor (Esping-Andersen 1999).

Utfallet är inte entydigt. Anpassningen har inte lett till mer ensartade välfärdsstater (Montanari, Nelson \& Palme 2008; Caminada, Gouds-

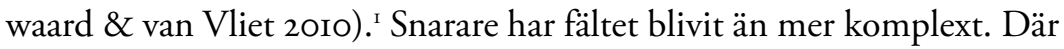
man tidigare målade i ideologiska färger - socialdemokratiskt styre ledde till socialdemokratiska välfärdsstater, etc. - finns i dag en oöverskådlig

I. Graden av konvergens är omdiskuterad. För en kritik av forskningsläget, se Schmitt \& Starke 20II.

Artikeln har skrivits inom ramen för projektet "It happened here. The Norwegian pension reform, process and content", finansierat av Norges forskningsråd. Jag vill tacka projektgruppens medlemmar för råd och stöd under arbetets gång, och särskilt Axel West Pedersen utan vars hjälp denna artikel aldrig blivit skriven. Varken han eller någon annan skall dock lastas för eventuella fel och brister. 
välfärdsmix som trotsar alla försök till enkel klassificering: ideologisk, nationell eller institutionell (Hort 20I4, s. 26-27). En annan tendens är att forskningen hamnat nära beslutsfattarnas egen problemvärld, där utmaningen är att övertyga medborgarna om att "evigt ej kan bli det gamla” (Lundberg 2009). ${ }^{2}$ Grundfrågan är i varje fall densamma: Hur reformerar man populära välfärdssystem utan att skapa missnöje? (Weaver 1986.) Enkla lösningar saknas och metoderna varierar, både mellan länder och inom länder mellan olika program (Pierson [red.] 200I). Strategiska element tycks fälla avgörandet. En framgångsrik reform är en reform som är maximalt förankrad i sin egen politiska kultur och som förhåller sig kreativt till den aktuella institutionens utformning och historia (Lundberg, Kangas \& Ploug 20IO).

Forskningsstrategiskt har detta inneburit att en tidigare strävan efter övergripande förklaringsmodeller - funktionalism, marxism, institutionalism och maktresursteori - ersatts av en böjelse för komplexa analyser som samkör förklaringsvariabler, blandar teoretiska perspektiv och begreppsliggör olika reformdimensioner (Korpi 1983; Esping-Andersen I990). ${ }^{3}$ Komplexiteten hamnar i förgrunden, vilket yttrar sig i studier som framhäver variabler som "policyreformutrymmenas multidimensionalitet", "konfliktlinjernas och allianspotentialernas pluralitet", "välfärdsinstitutionernas underliggande aktörskonfigurationer och varierande koalitionsbas" (Lynch 2006; Häusermann 20I0). Iakttagelserna har förstås sitt värde, men frågan är hur mycket klokare man blir av att generalisera politikens interna komplexitet. Politiken blir dunkel i stället för genomskådlig och den maktpolitiska dimensionen, som fortfarande levde 1994 i Paul Piersons Dismantling the welfare state?, försvinner nästan helt och hållet (Pierson 1994). ${ }^{4}$

En större fråga är förstås vad mer som finns kvar att förstå "när filosofin målar sitt grått i grått”, som Hegel säger i förordet till sin rättsfilosofi (Hegel 2005 [I82I], s. xxi). Det är detta tillstånd, historiens slut som det populärt kallas, som ligger i förlängningen av hans metafor om Minervas uggla som breder ut sina vingar i skymningsljuset: det finns en punkt där kunskapen tränger ut politiken. För Hegel var detta en upplivande

2. Citatet ur Esaias Tegnérs dikt "Hjelten" från I813, Tegnér I959 [I828], s. I69.

3. Se Hort 2OI4, s. I5-28, för ett panorama över de senaste decenniernas välfärdsforskning. 4. För en utveckling på detta tema, se Lundberg 2009. 
bild, ett uttryck för att han levde i ett "intellektuellt kungadöme" som visste och ville sig självt och därför visste vad det ville, och viktigare: som handlade "i enlighet med en bestämd kunskap om förhandenvarande omständigheter och förhållanden i den mån dess handlingar berör dessa” (Hegel 2005 [I82I], s. Xxi).

\section{Femtio nyanser av grått}

Är det mot denna bakgrund vi bör se den norska pensionsreformen från 2009? Ugglan har lyft. Endast variationer över samma tema återstår. Helt visst har reformen hamnat i skymundan på den globala policymarknaden och figurerar inte nämnvärt i den komparativa forskningen, trots enstaka försök att fästa uppmärksamhet vid dess existens. ${ }^{5}$

Så är den också en senkomling bland pensionsreformer, även i ett nordiskt sammanhang. ${ }^{6}$ Den verkar inte tillföra mycket nytt. Axel West Pedersen har kallat den en "mjukisversion av den svenska prototypen" och en "halvhjärtad kopia av ett brutalt original" (West Pedersen 2005, s. 9; West Pedersen 2004). Inte heller den politiska inramningen var speciellt spektakulär, och reformen låter sig utan vidare inlemmas i de nya välfärdsforskarnas multidimensionella policyutrymmen och överlappande reformkoalitioner. Mönstret känns igen från andra länder, både i Norden och på kontinenten (West Pedersen 2009). Järtecknen hopade sig i skyn. Experterna slog larm om höjd medellivslängd, tidiga pensionsuttag, finansieringsproblem och förlorad konkurrenskraft. Därefter vidtog arbetet med att koordinera eliter och orkestrera majoriteter bakom reformförslag som skulle säljas till en förmodat misstänksam väljarkår inom ramen för en genomtänkt kommunikativ diskurs (Ervik \& Skogedal Linden 2015).

På sin höjd tycks den norska pensionsreformen alltså addera ytterligare nyanser till den allmänna gråskalan. En skillnad är möjligen att debatten inte ens under de första åren följde en traditionell dynamik där de politiska aktörerna agerade ut sina ideologiska motsättningar

5. För ett försök att karakterisera den norska pensionsreformen, se Fredriksen \& Stølen 20II. Norge inkluderas sällan i internationella översikter. Undantag är Whitehouse, D’Addio, Chomik \& Reilly 2009 samt Marier 2014.

6. I en studie som omfattar trettio EU- och OECD-länder listar Whitehouse, D'Addio, Chomik \& Reilly 2009 Norge i gruppen "senkomlingar". 
(West Pedersen 2009). I Sverige smög sig kunskapen om Hegels förhandenvarande omständigheter på efter hand, över en period på cirka femton år. Riksdagsbeslutet om principer för ett nytt pensionssystem 1994 föregicks av en utdragen politisk konflikt med djupa historiska rötter (Lundberg 2003). I Norge framstår däremot inslaget av lärprocess som ytterst begränsat. Reformkoalitionen som etablerades 200I var stadigt förankrad i det postindustriella problemkomplexet och tvivlade aldrig på de hotfulla demografiska kurvornas absoluta vederhäftighet. Alla inblandade talade, som det heter, förnuftigt redan från första början (Ervik \& Skogedal Linden 2015).

\section{Pensionsreformer i överflödssamhället}

Möjligen är det för tidigt att avskriva den norska pensionsreformen som bara mer av samma sak. En väsentlig fråga är varför det tog så lång tid varför detta sena uppvaknande? En annan fråga är varför man nöjde sig med en mjukisversion av det brutala svenska originalet. En tredje fråga är varför man använde en svensk prototyp när det fanns alla förutsättningar att göra något originellt eller egensinnigt.

Man kan till och med fråga sig varför politikerna över huvud taget gav sig i kast med en pensionsreform. Väljarna var inte mobiliserade i frågan. Ekonomin ställde inga omedelbara krav. Flyger man in över den norska Atlantkusten står oljeplattformarna på rad, vilket vittnar om att Norge är allt annat än ett vanligt solkigt och sargat västland. Oljeproduktionen går alltjämt för högvarv. Statens pensjonsfond utland, som förvaltar oljeintäkterna, hade vid utgången av 2014 ett marknadsvärde på 6432 miljarder norska kronor. Den gigantiska aktieportföljen, med investeringar i 8 ooo bolag i 82 länder, rymmer I, 3 procent av alla aktier i hela världen. ${ }^{7}$ Trots sjunkande oljepriser på senare år gör det den till en av världens största fonder alla kategorier. ${ }^{8}$ Egentligen är den bara en pensionsfond till nam-

7. Statens pensjonsfond består av två fonder: Statens pensjonsfond utland och Statens pensjonsfond Norge. Den förstnämnda är den avgjort största (Norges Bank 20I5).

8. Oljeproduktionen har fallit det senaste årtiondet. 200I uppgick den till 3,4 miljoner fat per dag (ett fat är I59 liter). 20 Io hade den sjunkit till 2,I miljoner fat. Norge hamnar därmed på trettonde plats bland oljeproducenterna. För nio år sedan var Norge världens sjätte största oljeproducent och var ännu viktigare på exportmarknaden eftersom två av de stora producenterna, USA och Ryssland, också är stora konsumenter. 
net eftersom den inte finansieras av pensionsavgifter, men på den norska regeringens hemsida tydliggörs ändå dess status av en sparslant för framtida pensionärsgenerationer:

Formålet med Statens pensjonsfond er å understøtte statlig sparing for finansiering av folketrygdens pensjonsutgifter og å underbygge langsiktige hensyn ved anvendelse av statens petroleumsinntekter. [...] I lys av at pensjonsutgiftene i folketrygden vil øke sterkt gjennom de neste tiårene, er en betydelig fondsoppbygging i årene framover nødvendig for å unngå å skyve store byrder over på kommende generasjoner. ${ }^{9}$

På goda grunder kan man alltså argumentera för att oljepengarna innebär att den norska pensionsreformen hamnar snett, i förhållande både till reformer i andra länder och till det dominerande forskningsparadigmet, enligt vilket pensionsreformer per definition är uttryck för ett lands förmåga att anpassa sig till ett kärvare ekonomiskt och socialt klimat (Myles \& Pierson 200I; Bonoli 2000). I litteraturen tillkommer nya pensionsreformer med kniven mot strupen. Befolkningen åldras, ekonomin omstruktureras, arbetslösheten permanentas och medborgarnas krav på service blir allt dyrare att tillgodose, samtidigt som den globala konkurrensen gör det allt svårare att täcka utgiftsökningar med nya eller höjda skatter (se till exempel Rieger \& Liebfried 2003; Pierson [red.] 200I; Swank 2002). I mångt och mycket utgår de senaste decenniernas välfärdsforskning från denna beslutssituation - "det dubbla trycket från global och demografisk förändring", som det kallats - där politiker från alla partier riskerar att stöta sig med både väljare och välorganiserade intressegrupper (Bonoli, George \& Taylor-Gooby 2000). ${ }^{\text {Io }}$

Den norska pensionsreformen blir ett slags anomali i förhållande till kunskapen för dagen. Även om oljefonden inte är outtömlig, är den

9. Från https://www.regjeringen.no/no/dep/fin/org/etater-og-virksomheter-underfinansdepartementet/underliggende_etater/statens-pensjonsfond---utland/id2704Io/, hämtat 5 augusti 2015 .

ı. Genom hela artikeln talar jag om "den nya välfärdsforskningen" och "de nya välfärdsforskarna". Med dessa fraser åsyftar jag vad som i den internationella litteraturen brukar kallas "the new politics of the welfare state" eller helt enkelt "new politics", det vill säga att politikerna numera tvingas skära ned eller bygga om välfärdssystem i stället för att som under efterkrigstiden bygga ut och förbättra. En klassiker på området är Paul Piersons bok Dismantling the welfare state? från 1994. 
tillräckligt stor för att politikerna borde vara frestade att dröja vid det gamla. Varför utsätta sig för väljarnas vrede i onödan? Varför ge sig i kast med något som lätt går överstyr? (Pierson 1994; Green-Pedersen 2002; Pierson 1996; Kuhnle 2000; van Kersbergen 2000.) Varför inte pröva något originellt när det råder överflöd? Vidare får kritikerna ett försteg i opinionen. I jämförelse med reformatörer i andra länder, där anpassningskraven slår an ett ihållande grundackord som dränker alla kritiska röster, får de norska bära en större del av förklaringsbördan. Ty även om prognoser vittnar om att oljan sinar omkring 2030, tyder andra prognoser på att oljefonden kommer fortsätta växa i all framtid om den förvaltas förståndigt. ${ }^{\text {II }}$

\section{Normaliseringslinjen i norsk välfärdsdebatt}

Är den norska pensionsreformen en abnormitet? Om teorin lär att pensionsreformer är ett slags kris- eller omställningspolitik, hur kunde den komma till stånd i Norge där omständigheterna är så annorlunda? Eller mer precist: Varför gjorde sig norska politiker omaket att driva igenom en pensionsreform av svenskt snitt i ett läge där det fanns tillräckligt med resurser för att bevara det gamla systemet under en överskådlig framtid? Man kunde också ha tänkt sig en lösning i linje med de finska och danska reformerna, som byggde på ett större mått av kontinuitet (Kangas 2007).

Norge är utan tvekan världens rikaste land. Statsskulden är obefintlig. Årliga budgetunderskott kalibreras mot oljefondens kapital. Ekonomin växer, produktiviteten är hög och arbetslösheten låg. 2005 var den 4,6 procent, förstklassiga siffror i europeiskt sammanhang. Sysselsättningsgraden var långt över OECD-genomsnittet (Halvorsen \& Stjernø 2008,

I I. Trots sjunkande oljepriser tjänar Norge fortfarande rejält på sina oljefält. Enligt amerikanska Monitor Group som följer statsägda förmögenhetsfonder (sovereign wealth funds), alltså fonder i råvaruproducerande länder och länder med stora exportöverskott, har den norska oljefonden nu passerat Förenade Arabemiratens fond, Abu Dhabi Investment Authority. Till detta skall läggas förhoppningarna som knyts till ny teknologi och naturgasen som inte förväntas ta slut förrän cirka $2080 \mathrm{om}$ inga nya fyndigheter påträffas. 
s. 43-49). ${ }^{\text {I2 }}$ Till och med demografin förefaller mindre alarmerande än i jämförbara länder. Fram till 2050 uppskattas antalet personer i befolkningen som är 65 år eller äldre stiga till 45 procent, vilket är nästan en fördubbling. Bördan är förstås ansenlig med hänsyn till hur den påverkar pensionsutgifterna, men siffrorna är ändå förhållandevis moderata. Motsvarande uppskattning för Sverige och Tyskland är 55 procent och för Italien 65 procent. ${ }^{13}$

Utmaningar saknas alltså inte. Men i jämförelse med övriga Europa framstår de ändå som mindre oroväckande, och viktigare: de avtecknar sig i ett gynnsamt samhällsekonomiskt läge. Sammantaget befinner sig den norska pensionsreformen i ett märkligt vakuum. Reformprocessen borde aldrig ha inletts, och när den väl inleddes borde den inte ha lyckats. Därtill blev det en reform som faller in i ett jämförelsevis dramatiskt svenskt mönster: avgiftsbestämda pensioner i kombination med flexibel pensionsålder, förlängd intjänandetid och stärkt försäkringsmässighet (Fredriksen \& Stølen 20II). Hur kan detta vara möjligt? Medan den svenska reformen tillkom i den djupaste av kriser tillkom den norska i det yppigaste av överflöd. ${ }^{14}$

$\mathrm{Nu}$ behöver detta inte vara så egendomligt. I själva verket står även den norska välfärdsstaten inför anpassningskrav, de är bara svårare att åskådliggöra. Det är i korthet den linje som drivs av de flesta norska samhällsforskare, och framför allt den linje som förfäktas av ett förhållandevis enigt etablissemang av experter och politiker. Visst - ekonomin går som tåget, arbetslösheten är låg och konsumtionskraften hög. Oljan genererar rikedomar. Men så småningom tar den slut, och ser man

I 2. Den norska arbetslösheten är fortfarande anmärkningsvärt låg. I april 2015 låg den på 4,2 procent mot 9,7 för EU-genomsnittet, och då har den ändå stigit något sedan 2014 (se Statistisk sentralbyrå 20I5).

I3. Fram till 2050 beräknas Norges pensionsutgifter mer än fördubblas, från 9, I procent av BNP 200I till nästan 20 procent 2050 (Halvorsen \& Stjernø 2008, s. 158-I59).

I4. Francis Sejersted tangerar detta märkliga faktum när han frågar sig varför utvecklingen i de båda länderna gick parallellt (Sejersted 2005, s. 4I8): "Samma problem dök upp, och samma lösningar provades - i stort sett. Detta är anmärkningsvärt eftersom statsfinanserna gick i motsatt riktning. I början av 1990-talet lades statsskulden på hög i Sverige, medan överskotten lades på hög i Norge. Sverige tvingades till mer drastiska åtgärder än Norge. Men bekymren var i stort sett desamma.” 
bortom den - som om den aldrig funnits - står det klart att Norge har samma omställningsproblem som alla andra länder. ${ }^{\text {Is }}$ Dessutom: Varför inte smyga igenom impopulära reformer när tiderna är goda i stället för att invänta nästa kris?

Man kan kalla det en normaliseringslinje i norsk välfärdsdebatt: en önskan om att bli insläppta i samma intellektuella kungadöme som alla andra. Även norsk politik varierar över det postindustriella temat. Även i Norge lever människor allt längre. Även i Norge föder kvinnor för få barn. Även i Norge lämnar människor arbetsmarknaden för tidigt. Även i Norge ägnar sig politikerna åt att administrera den globala nödvändighetens lokala effekter. Även i Norge breder ugglan ut vingarna i skymningsljuset. Normalisering innebär inte att Norge är som alla andra länder - alla tycks eniga om att omständigheterna är sällsynt goda - utan att det i slutänden är omöjligt att driva en självständig politik utanför allfarvägarna. Ställer Europa om till en postindustriell problemvärld, måste Norge också göra det (se anslaget i Hatland [red.] 20II).

I förlängningen av normaliseringslinjen ligger en förmodan om att det i själva verket är svårare att genomdriva reformer i Norge än i andra jämförbara länder. Visserligen bör man resonera "oljeneutralt” eller "oljekorrigerat", men eftersom oljeplattformarna står där de står blir det besvärligt att övertyga väljarna om behovet av att snäva in och strama åt i stället för att förbättra och bygga ut. "De stora förväntningarnas missnöje”, som Tage Erlander kallade människornas anspråk på samhället $\mathrm{i}$ tider av ökat välstånd, är aldrig långt borta (citerat ur Ruin 1986, s. 236). Dagens norska överflödsproblematik för också tankarna till svensk efterkrigstid, men där Tage Erlander kunde slå mynt av människors "drömmar och förhoppningar" värjer sig dagens norska politiker för deras oförnuft och xenofobi, samt deras växande fäbless för Fremskrittspartiet (Andersen \& Bjørklund 2000; Andersen \& Bjørklund 2008). Det skulle också kunna förklara varför den norska pensionsreformen kom så sent

I 5. Mer om detta längre fram. Här räcker det med att konstatera att tendensen att inordna Norge i ett allmäneuropeiskt krismönster är mycket stark i pensionskommissionens rapport från 2004. Se även Ervik \& Skogedal Linden 2015, vars genomgång av norsk mediedebatt 1995-20I3 visar att den journalistiska bevakningen kopplade samman pensionsreformen med ord som eldrebølgen och generasjonsregnskap. 
som den gjorde. Det var svårt, mycket svårt, men till slut lyckades man. Även det nya systemets design kan förstås i detta ljus. Det var svårt, mycket svårt, och just därför blev det en mjukisversion av den svenska prototypen.

Normaliseringslinjen har mycket fog för sig. Det beror inte minst på att norsk politik i mångt och mycket är grundad i en stark vilja att tillhöra en europeisk mittfåra. Eller bättre uttryckt: en stark vilja att vara bäst $\mathrm{i}$ klassen utan att riskera att flyttas upp en årskurs. Det finns historiska skäl till detta. Omställningen från ett land som andra till ett land utan jämförelsepunkter gick mycket snabbt och har varit svår att härbärgera för den nationella identiteten (se Sejersted 2005, s. 515-518). Men som sagt vilar normaliseringslinjen också på ett slags rationalitet. Möjligheten att träda fram som en prålig gulfstat mitt i ett krisdrabbat Europa utövar måhända en lockelse på vissa, men för både etablissemanget och en enig forskarkår representerar en sådan självhävdelse ett första steg ut på det sluttande planet (Halvorsen \& Stjernø 2008, s. 157). Häri ligger en tydlig konflikt i norsk politik, mellan dem som accepterar självtukt och återhållsamhet som politikens yttre ram och dem som inte gör det. Konfliktlinjer löper både mellan partierna - eller mellan etablerade partier och Fremskrittspartiet - och inom partierna och mellan medborgare och elit (Halvorsen \& Stjernø 2008, s. 157, I6r; Andersen \& Bjørklund 2008).

Detta innebär att den nya välfärdslitteraturens problemvärld är fullt tillämplig på Norge. Man kan även säga att den radikaliseras något eftersom den politiska eliten inte kan gömma sig bakom den gängse kris- och nödvändighetsretoriken (Watson \& Hay 2003; Ryner 2002). I Sverige kändes krisen in på bara skinnet. I Norge ges den karaktären av en "alternativrisk", ett scenario som kan bli verklighet om de gynnsamma kort som tilldelats spelas på ett oskickligt sätt. ${ }^{16}$ Det handlar inte självklart om att bestrida medborgarnas sinnesintryck - oljeplattformarna står där de står - utan dels om att övertyga dem om att "evigt ej kan bli det gamla", dels om att få dem att förstå att Norges särställning ytterst vilar på en genomtänkt måttfullhet: vi är inte ett land som alla andra men vi kan bli det om vi inte gör som alla andra.

I6. Begreppet "alternativrisk" har hämtats från Forslund 2008. 


\section{Det normala eller abnorma Norge?}

Så vilket perspektiv är mest trovärdigt: det abnorma eller det normala Norge? Inget av dem är helt tillfredsställande. Framhäver man abnormiteten får man svårt att förklara varför reformen genomfördes. Visst, man kunde låtit bli, men man valde ändå att göra det. Fokus hamnar på räddhågsna eller svekfulla eliter som inte vågade välja en egen väg. Framhäver man normaliteten tvingas man förtränga att man kunde ha låtit bli eller valt en annan väg. Överflödet blir ett oförklarat $x$ i förståelsen. Man får också förlita sig på bristfälliga förklaringar till att reformen kom så sent och att den utformades som den gjorde. Visst, det var svårt, men var det svårare än i andra länder? Visst, det var svårt, men innebar inte överflödet att man förfogade över en bredare repertoar än andra länder? Och även om man inte kunde bli vid det gamla återstår frågan varför man gjorde som i Sverige. Varför utnyttjade man inte att Hegels "förhandenvarande omständigheter" såg annorlunda ut?

I denna artikel har jag valt en delvis annorlunda ingång i den norska pensionsreformen och tar fasta på hur den problemvärld som oljepengarna skapar interagerar med den postindustriella problemvärld som välfärdsforskningen pekar ut. Till saken hör att dessa två mycket långsiktiga perspektiv vilar på två tämligen olikartade framtidsscenarier. Det ena handlar om peak oil och tar fasta på dagen då oljan tar slut, det andra handlar om åldrande demografi och tar fasta på dagen då andelen äldre i befolkningen på allvar börjar slå mot ekonomins konkurrenskraft. Därför väljer jag en medelväg mellan abnormitet och normalitet. En central fråga i sammanhanget är varför den politiska eliten valde att slå in på en normaliseringsväg och reducera Norge till en variation över det gängse postindustriella temat. Denna fråga menar jag är omöjlig att besvara utan att gå omvägen via oljan. Mer konkret kan man uttrycka det som att det dubbla trycket från globalisering och demografi, som i olika grad plågar alla andra jämförbara länder, i Norge filtreras genom en ännu större fråga om vad som kommer hända när oljeinkomsterna upphör, eller mer korrekt: den dag oljan är borta och pengarna har använts på ett oklokt sätt.

För att ytterligare framhäva särdragen i norsk politik kommer jag att sätta in reformprocessen i en nordisk - oljelös - kontext där särskilt det 
svenska exemplet ges en avgörande betydelse. Som antytts sneglade de norska reformatörerna både på den svenska reformens utformning - den så kallade NDC-modellen - och på hur den svenska reformprocessen strukturerades - upprättandet av en policykartell som omfattar en permanent majoritet i parlamentet. ${ }^{17}$ Men återigen är det viktigt att betona att de gjorde det under omständigheter som skilde sig radikalt från de svenska. En närmare analys visar att det av detta skäl rör sig om två tämligen olikartade pensionssystem och två tämligen olikartade reformprocesser. Om man tillåter sig att tala dunkelt orakelspråk kan man säga att de norska reformatörerna förvisso följde de svenska i spåren men att de både började och slutade på en annan plats.

\section{Sesam öppna dig}

När Ali Baba yttrat orden "Sesam öppna dig” och fått syn på de märkvärdiga skatter som gömde sig i de fyrtio rövarnas hemliga grotta sade han tyst till sig själv (här ur Tusen och en natt 20I2, s. I67): "Vid Allah, nu har ödet vänt ett välvilligt ansikte mot dig och placerat dig [...] mitt i ett hav av guld som bara kung Salomon har sett maken till. [...] Och om detta har hänt dig är det säkerligen för att du och dina barn i framtiden ska skyddas mot nöd och umbäranden.” Riktigt så enkelt var det förstås inte. Först måste både försåtliga rövare och giriga släktingar skaffas ur vägen. Icke desto mindre, när sagan är slut och rövarna gått en grym död till mötes får den fattige vedhuggaren, "vars enda förmögenhet var tre åsnor", behålla hela skatten för sig själv (Tusen och en natt 20I2, s. I62).

Upptäckten av olja i Nordsjön var inte lika omedelbar. När Svend Foyn, direktör vid Norges geologiske undersøkelse, nämnde oljan i ett brev till utrikesdepartementet den 23 februari 1958 var det inte heller i termer av en mystisk trollformel. Så här lät det (citerat ur Valebrokk 2004, s. 452-453): "Man kan regne med at kontinentalsokkelen utenfor den norske kyst består av de samme bergartformasjoner som på land i tilsvarende område. Man kan ikke se bort fra muligheten for at det skulle finnes kull, olje eller svovel på kontinentalsokkelen langs den norske kyst.”

I7. Om begreppet "policykartell”, se Weaver 2006. Om policykartell i anslutning till den svenska pensionsreformen, se Lundberg 2009. 
Det var försiktigt formulerat och först efter påstötningar från ett amerikanskt oljebolag tog norska politiker tillfället i akt. På några få år utverkades de nödvändiga territoriala anspråken (Sejersted 2005, s. 372-376). Drygt tio år senare påträffades den första oljan. Därefter gick det fort. I början av I980-talet hade Norge övertagit ledartröjan i Norden om man ser till BNP per capita (Røed Larsen 200I).

Det är svårt att överskatta oljans betydelse för Norges ekonomi och samhällsliv. Den går på djupet, griper tag i historien och styr in den på vägar som är svåra att överblicka. Den utgör också en utmaning för varje försök att förstå norsk samtidshistoria, inte minst eftersom den så att säga dränker varje försök att importera teorier som är baserade på en generell europeisk erfarenhet. En tidig insikt bland norska politiker var att oljan rymde en särskild moral, att man inte kunde spendera pengarna den genererade utan tanke på morgondagen. Rikedomarna måste spridas till hela befolkningen, också till kommande generationer, och användas på så vis att de bidrog till att utveckla det norska samhället (Holden 20II; Sejersted 2005, s. 372-376).

Sagan om Ali Baba och de fyrtio rövarna rymmer liknande lärdomar. Rövarnas guldskatt kräver förvisso ingen motprestation. Den finns där och tillkommer den som är förståndig nog att lägga beslag på den. Men girighet och oförstånd bestraffas. I slutänden är det Ali Babas fromhet, hans omsorger om familj och tjänstefolk, som fäller avgörandet.

Även i övrigt påminner oljan om sagans flödande guldskatter. I likhet med en guldkista är olja en icke-förnybar resurs. När den är slut är den slut. Inga egentligt nya värden har skapats under tiden. ${ }^{18}$ Till detta skall läggas att de sektorer som etablerats för att betjäna oljeutvinningen, i dag en försvarlig del av norsk ekonomi, förväntas få stora svårigheter i samma ögonblick som oljeintäkterna upphör. ${ }^{19}$ Ett mer omedelbart problem är att intäkterna från oljesektorn (på samma sätt som intäkter från guldsektorn) varierar kraftigt över tid vilket ger stora planeringsproblem (Ramey \& Ramey 1995; Gylfason 200I; Gylfason 20II). Den ständigt närvarande risken är att man skaffar sig vanor som blir svåra att upprätthålla när

I 8. Detta argument, som lanserades i Tempoutvalgets slutrapport 1983 (NOU I983:27) har haft stor betydelse i den norska debatten.

I9. Se till exempel St. meld. nr. 29 (2000-200I). 
borrhålen torkat ut eller om marknaden faller och priserna störtdyker. Sensmoralen är att fattigdom alltid är ett elände men att den är ännu svårare att fördra om man en gång har varit rik. ${ }^{20}$ Generationsaspekten måste också vägas in - det orättfärdiga i att förslösa en enorm och i ärlighetens namn oförtjänt förmögenhet utan tanke på dem som kommer efter och att i värsta fall därtill efterlämna en betydande skuld.

En annan besynnerlighet är att oförtjänta rikedomar nästan alltid omgärdas av diverse trolltyg. I oljans värld går de under namnet naturresursförbannelsen. Begreppet myntades av ekonomen R. M. Auty, som i en bok 1993 frågade sig varför världens fattigaste länder också har de rikaste naturresurserna medan världens snabbast växande ekonomier saknar motsvarande tillgångar (Auty 1993). Sambandet var inte bara kontraintuitivt, det gick också på tvärs med klassisk utvecklingsekonomi, som ser tillgång på naturresurser som avgörande för tillväxt och välfärd. ${ }^{21}$ Tesen fick vidare acceptans 1996 när ekonomerna Jeffrey D. Sachs och Andrew M. Warner presenterade ett statistiskt säkerställt bevis på sambandet mellan ekonomisk tillväxt (mätt i BNP per capita) och storleken på naturresurssektorn (Sachs \& Warner 200I).

Sachs och Warner uppehöll sig framför allt vid naturresursernas effekter på tillväxten, nämligen att de tenderar att resultera i korruption och förtärande fördelningskonflikter - bad policy som man säger. Andra forskare framhäver att den ekonomiska strukturen snedvrids. Fenomenet går under många namn: undanträngning (crowding out), holländska sjukan, överflödsparadoxen (Karl 1997). Tanken är att naturresursproduktionen leder till ökad offentlig konsumtion och därmed till ökade kostnadsnivåer, vilket underminerar de delar av ekonomin (Fastlands-Norge, som man säger i Norge) som inte har med naturresursen att göra. Detta resulterar i sin tur i att ekonomins mångfald minskar och landet blir än mer beroende av sina naturtillgångar, med förödande konsekvenser när naturresursen en dag tar slut (Ross 20I2). Både förbannelsen och sjukan kan beläggas med historiska och aktuella exempel: Nigeria, Gabon, Irak, Venezuela, Sudan, såväl som Spanien och Portugal efter koloniseringen

20. Se resonemang i St. meld. nr. 29 (2000-200I).

2 I. Redan Adam Smith hävdade att naturresurstillgångar är en viktig för att inte säga avgörande faktor bakom ekonomisk tillväxt (Smith I909-I9II [I776]). 
av Sydamerika. Det vill säga länder som trots rika guld- och oljefyndigheter har fastnat i fattigdom, ojämlikhet och vanstyre och en negativ ekonomisk spiral (Karl 1997). Varken förbannelsen eller sjukan är förbehållen krigshärjade utvecklingsländer. Ett modernt europeiskt exempel är Holland, som under efterkrigstiden fastnade i ett långsiktigt beroende av naturgasproduktion (Holden 20II; Ross 20I2).

Men det finns också flera undantag, däribland Norge, Kanada, Storbritannien och USA. ${ }^{22}$ En senare generation forskare har därför valt att kombinera ekonomiska och institutionella argument. Slutsatsen är att både förbannelsen och sjukan är ständiga hot, men att risken är mindre i länder med en folkligt förankrad politisk kultur, transparenta demokratiska institutioner, viss industrialiseringsgrad, varierad ekonomi och ett stabilt rättsväsende som motverkar korruption och politisk vanskötsel (Mehlum, Moene \& Torvik 2006; Røed Larsen 200I). Men inte ens under dessa förutsättningar är det enkelt. Även Norge har periodvis haft en släng av holländska sjukan. ${ }^{23}$ Vissa ekonomer antyder till och med att norsk ekonomi möjligen hade utvecklats bättre om oljan aldrig hade upptäckts (Røed Larsen 200I). Något entydigt samband verkar det inte finnas. Olja kan vara både en välsignelse och en förbannelse, leda till både glädje och sorg. ${ }^{24}$ Utfallet tycks vara beroende av hur den interagerar med de politiska institutionerna. ${ }^{25}$

22. Se Ross 2012 för en översiktlig och lättillgänglig introduktion till fältet som helhet som dessutom i första hand koncentrerar sig på oljans särskilda egenskaper.

23. Det som i första hand avses är att norsk ekonomi periodvis utmärkts av låg produktivitet trots hög investeringskvot. Se Cappelen 2002.

24. Jämför storvinster på lotteri, som inte alltid leder till ett bättre liv. I extremfallet kan det gå riktigt illa. Som för Jack Whittaker, en framgångsrik företagare från West Virginia som på juldagen 2002 vann 315 miljoner dollar. Den älskade dotterdottern började knarka och frun lämnade honom efter att han rånats på 500 ooo dollar på en strippklubb (Petersson 2009). Michael L. Ross kallar fenomenet "oljerikedomarnas ironi”: de länder som har de mest trängande behoven har sämst förutsättningar att dra nytta av geologiska fynd. Ross 2012, s. 2.

25. De flesta studier landar i denna slutsats även om exempelvis Karl 1997 menar att oljan på ett eller annat sätt alltid är skadlig. Antingen är det institutionerna som ställer till problem för oljan eller så är det oljan som ställer till problem för institutionerna. Riktigt bra blir det aldrig. Denna tes ifrågasätts dock kraftigt av många norska ekonomer som tycker sig kunna visa att den norska ekonomin mår påfallande väl trots det relativa oljeberoendet. 
Balansgången mellan olja och politik är hårfin, inte minst eftersom oljan skapar förväntningar om tydliga välfärdsvinster. Man kan säga att norsk politik utspelas i det skarpa skenet av de möjligheter som oljan ger. Frånvaron av en bro över ett sund blir mer påtaglig än i länder utan motsvarande tillgångar. En pensionär som far illa på ett ålderdomshem eller sjukhus, skolor och barnomsorg som ger dålig service, blir mer upprörande. Detsamma gäller fattiga pensionärer, eller pensioner som blir lägre än förväntat, eller pensioner som avspeglar någon orättvisa. Alla vet att pengarna finns där, men alla accepterar inte att staten värjer sig för att investera dem där de kunde göra nytta. Det ger debatten en särskild karaktär. Den handlar mindre om vikten av att anpassa sig till strukturella begränsningar och mer om vikten av att upprätthålla självpålagda begränsningar.

\section{De tio oljebudorden}

Redan från början fanns en utbredd insikt om att man måste närma sig oljan med varsamhet. En rad frågor väcktes. Hur skulle man få upp den ur havsbotten, hur skulle inkomsterna förvaltas, till vad skulle de användas, hur skulle integrationen i den internationella oljeekonomin administreras? De tio så kallade oljebudord som Stortinget antog i juni 1972 ger en ingång i hur man tänkte. Oljan skulle utvinnas under statlig kontroll i syfte att befrämja samhället som helhet, och framför allt: intäkterna skulle integreras i den befintliga ekonomin. Här spelade inte minst det holländska exemplet in, som norska politiker studerade med intresse. Oljan var en välsignelse och just därför var det viktigt att hålla huvudet kallt (Sejersted 2005, s. 372-376; Holden 20II; Røed Larsen 2006).

Därmed inte sagt att resan varit enkel. Under de första decennierna var oljan främst en utgiftspost. Enorma investeringar skulle till och nödvändig kunskap byggas upp. När oljan påträffades i slutet av 1960-talet var det få eller inga norrmän som visste vad man skulle göra med den. Oljepolitiken har också fått förändrat innehåll över tid och har inte bara påverkats av ekonomiska konjunkturer utan även ideologiska skiften och ändrade maktförhållanden (Sejersted 2005, s. 372-376). 
I970-talet dominerades av Arbeiderpartiet, som försökte finna en formel för att förena den småskaliga norska ekonomin med det internationella oljekapitalet utan att förlora möjligheterna till samhällsutveckling ur sikte (Sejersted 2005, s. 372-376). Den ekonomiska betydelsen av denna ambition, att genom så kallad infant industry protection skapa ett norskt oljeindustriellt komplex, kan knappast ifrågasättas. Men den finns också andra förklaringar till den norska succén. OPEC-chocken som kastade ut hela västvärlden i en djupgående kris blev för norsk del "ett gyllene tillfälle", som Francis Sejersted konstaterar i en historik (Sejersted 2005, s. 374). Allt var dock inte frid och fröjd. Oljeverksamheten i kombination med växande offentliga utgifter bidrog mot slutet av 1970-talet till kraftiga kostnadsökningar inom den norska fastlandsekonomin, med allt vad det innebär av snedvriden handelsbalans och försämrad konkurrenskraft (Holden 20II). Det var därför ingen tillfällighet att redan Tempoutvalget, som tillsattes 5 mars 1982 för att utreda oljans effekter, diskuterade möjligheten att hantera rikedomarna inom ramen för en buffertfond som gjorde det möjligt att balansera inkomster och utgifter i mer planenliga former. Huvudargumentet var att oljeinkomster inte är resultatet av produktion i vanlig mening utan snarare ett slags värdeomvandling från naturresurs till finansiellt kapital (NOU 1983:27, s. 99).

I slutänden avrådde utredningen från fondmodellen. Risken, argumenterade man i slutbetänkandet, var att fondkapitalet skulle utöva en alltför stor lockelse på politikerna (NOU 1983:27, s. 90). I bakgrunden framskymtar ett kollektivt handlingsproblem inom ramen för ett demokratiskt system med ständiga regeringsskiften (Olson 1965; Elster 1985). Förr eller senare skulle frestelsen bli för stor, ansåg utredningen under ledning av centralbankschefen Hermod Skånland. Fonden skulle bli en bricka i spelet om makten. Barriärerna skulle bryta samman och oljepengarna skölja in över fastlandet och spola undan möjligheterna till en långsiktigt ansvarsfull ekonomisk politik (NOU I983:27, s. 90): ”Ut fra de holdninger vi kjenner både i det politiske miljø og generelt i befolkningen, er det vanskelig å tenke seg at hundretalls av milliarder blir plassert som fordringer i utlandet, samtidig som en står overfor udekkede behov innenlands, og kanskje også sviktende sysselsetting som nære og påtrengende problemer.” Tempoutvalget förordade därför att produktio- 
nen eller värdeomvandlingen skulle ske i långsammare takt än tidigare. I stället för att samla pengar på hög skulle man lämna kvar oljan under havsbotten så länge som möjligt (NOU I983:27, s. IO-I5).

1980-talet gick i mer borgerlig riktning. Nu blev syftet att avpolitisera oljan och finna former för oljeutvinningen som inte var lika tydligt knutna till ett nationellt ideologiskt projekt. Det innebar bland annat att stödet för idén om en statlig oljefond (som i realiteten innebar att staten drog sig tillbaka till en mer passiv roll) vann ökad acceptans. En annan nyckelfråga i sammanhanget gällde statens inblandning i de verksamheter som etablerats för att säkerställa att Norge fick del av den expertis och det kunnande som krävdes för att landet skulle kunna vara en rationell aktör på den komplicerade internationella oljemarknaden (Sejersted 2005, s. 372-376).

Under den konservative Kåre Willochs tid vid makten togs avgörande steg för att lossa de politiska knutarna. Bland annat skrevs idén om en statlig oljefond in i 1986 års långtidsprogram. På längre sikt vidtogs åtgärder för att privatisera delar av Statoilkoncernen och låta den fungera i marknadsmässiga former. Också den politiska inramningen försköts. Vid mitten av 1980-talet hade det politiska systemet fått vissa erfarenheter av svårigheterna med att administrera en naturresurs. Det gällde dels prisernas volatilitet, dels effekterna på den nationella ekonomin. I takt med att oljevolymerna växte, verksamheten professionaliserades och vinsterna ökade antog oljan ett slags överpolitisk status. Den fick något absolut över sig som man inte kunde bråka om utan snarare måste anpassa sig till, ungefär som till fjordarna, fjällen, det kylslagna klimatet och Atlantvindarna som piskade in över den långa kustlinjen. Oljan var ett grundvillkor. Även politikernas självförtroende steg. Kanske var de trots allt förmögna att hålla fingrarna borta från syltburken (Sejersted 2005, s. 372-376).

Förspelet till oljefonden kom i slutet av 1980-talet med Steigumutvalget och 1990 blev den slutligen verklighet (NOU I988:2I). Som en säkerhetsåtgärd integrerades fonden i statsbudgeten på så vis att den med automatik täckte upp eventuella underskott. Tanken var att politikerna inte skulle kunna ge sken av att de sparade i fonden samtidigt som de i realiteten lånade pengar för att finansiera ett växande underskott. Slös- 
aktighet skulle omedelbart synliggöras. En annan kungstanke var att fondens pengar endast fick användas för att finansiera ändamål som specificerats och getts prioritet i Stortingets budgetprocess. ${ }^{26}$

De lagar som reglerade fonden gjorde klart att oljepengarna endast fick investeras i utländska tillgångar. Dels skulle detta ge betydande ränteinkomster, dels ville man undvika att ökade investeringar i den inhemska ekonomin bidrog till att pressa upp ett redan ansträngt kostnadsläge. Regelverket försvarades med att de norska företagen gott och väl kunde tillfredsställa sina lånebehov på kapitalmarknaderna (Holden 20II).

Oljefondens tillkomst var i någon mån uttryck för ett slags mognadsprocess. Norge hade genomlevt flera decennier med växande oljeinkomster utan att falla i de fallgropar som olyckskorparna kraxade om. I stort hade pengarna använts i enlighet med de tio oljebudorden. Ekonomerna pekar ut ett flertal olika skäl till framgången. Det tyngst vägande tycks vara att naturresursen kvarstått under statlig kontroll: alla vinster tillfaller staten (genom att bolagen som står för driften betalar hög skatt på sina inkomster), staten äger ett eget oljebolag och staten äger marken där oljan finns. Till detta skall läggas fungerande politiska institutioner, ansvarsfulla och välorganiserade fackföreningar, välutvecklade och omfördelande välfärdsprogram samt ett förståndigt utnyttjande av de pengar som flyter in i ekonomin (Røed Larsen 2006).

Att sedan ekonomin förändrats i grunden är inget att orda om. Norge är oljedominerat på samma sätt som Sverige präglas av skogen och malmen. De positiva effekterna skall inte förringas. Oljeintäkterna har inneburit att den inhemska efterfrågan på varor och tjänster har vuxit mer i Norge de senaste decennierna än i något annat OECD-land. En annan påtaglig effekt är möjligheterna att med olika stabiliseringspolitiska åtgärder upprätthålla sysselsättningen i tider av internationell lågkonjunktur (Olsen 1995). Men förbannelsen anses vara ett ständigt närvarande hot. Avgörande är hur de gåvor som naturen så generöst tillhandahåller hanteras. Inledningsvis blev inte heller trycket på politikernas självbehärskning och kollektiva rationalitet så hårt som befarat. Fallande

26. Oljefonden ägs av Stortinget (formellt finansutskottet) som fungerar som ombud för den norska staten. Stortinget har i sin tur gett uppdraget att hantera fonden till Norges centralbank. Se Cappelen 2002. 
oljepriser och en långvarig lågkonjunktur innebar att inkomsterna från oljesektorn stagnerade och det var först 1996 som fonden började fyllas på med pengar (Cappelen 2002). Sedan dess har det gått desto snabbare.

\section{Olja och pensioner}

I en avlägsen mening var förstås pensionerna en integrerad del av denna cocktail. När ekonomin växte vidgades handlingshorisonten och på detta indirekta vis blev oljan trots allt en viktig del av finansieringsunderlaget för de förmåner norrmännen valde att bevilja sig själva. Därmed inte sagt att norsk välfärd är uppblåst av oljepengar. Snarare tvärtom. De avgörande reformerna beslutades innan oljan satte sin prägel på ekonomin och utmärks av ett slags måttfullhet i det nordiska sammanhanget. Det gäller även folketrygden, som 1967 beslutades i bred parlamentarisk enighet (Bjørnson \& Haavet 1994; Åmark 2005; Seip 1994; Salminen I993). I jämförelse med den svenska förebilden blev ersättningsnivåerna lägre, pensionsåldern högre och intjänandetiden längre. Det är inte för intet som statsvetaren Einar Øverbye påpekat att det norska pensionssystemet förhöll sig till det svenska ATP-systemet som en enkel folkbil till en Volvo i premiumklassen (Øverbye 200I).

Senare tillägg uppvisar dock vissa tecken på bättre tider. Hit hör den successiva utbyggnaden av förtids- och sjukpensionering under 1980och 1990-talen (Halvorsen \& Stjernø 2008, s. 80). Här sticker Norge ut $i$ ett internationellt sammanhang. För det första är regelverken generösa (jämför dock den danska efterlönen). För det andra tillkom de jämförelsevis sent. För det tredje slog eftertankens kranka blekhet till senare än på annat håll (Palme, Gruber \& Wise 20ıo). Även i Norge visade det sig omgående att förtidspensionering utan aktuarisk justering blev populärare än väntat, men reaktionen kom senare och systemet försvarades av fackföreningsrörelsen (West Pedersen 2009). För det fjärde blev den ett argument i debatten om det nya systemet. Där många länder utnyttjat sina pensionsreformer till att göra sig av med kostsam barlast - änkepensioner, förtidspensioner, etc. - blev förtidspensionen i den norska reformprocessen en bricka i förhandlingsspelet (West Pedersen 2009).

Det finns alltså tänkbara samband mellan olja och pensioner. Pensionssystem speglar många saker: maktförhållanden, ideologi, institutio- 
nellt arv, politisk kultur, reformkapacitet, grad av industrialisering och modernisering. Men de speglar också strukturella begränsningar och de möjligheter som ekonomin tillhandahåller. Ett rikt land som flyter omkring på ett hav av olja har andra möjligheter än länder som inte gör det och som saknar motsvarande förutsättningar att bygga upp långsiktiga överskott i ekonomin. Manöverutrymmet i reformprocessen blir helt enkelt större. Samtidigt är det viktigt att poängtera att relationen mellan olja och välfärd förändras när den formuleras inom ramen för den problematik som välfärdsforskarna pekar ut. När ekonomen Erling Røed Larsen förklarar varför Norge klarat sig undan både förbannelsen och sjukan tillskriver han välfärden och jämlikhetssträvanden inom ramen för en växande ekonomi en viktig roll. Om inte annat tycks en stor välfärdssektor som upprätthåller en hög offentlig efterfrågan i ekonomin skapa förståelse för de självpålagda begränsningar som måste till för att inte oljeintäkterna skall gå ut över ekonomin som helhet. Om medborgarna har förtroende för att politikerna vill deras bästa och varken berikar sig själva eller sina vänner, kan de leva med att värdeomvandlingen från olja till pengar inte omedelbart resulterar i mer och bättre välfärd.

Røed Larsen tecknar konturerna av ett "socialt kontrakt", där regeringens möjlighet att placera oljepengarna i utländska finansiella tillgångar i stället för att öka den inhemska konsumtionen vilar på dess förmåga att upprätthålla medborgarnas välfärd och välstånd (Røed Larsen 2002, s. 2I). Värt att påpeka är dock att ekonomernas argumentering utgår från historiska fakta. Man får en förklaring till att Norge till skillnad från länder som Nigeria och Venezuela undkommit förbannelsens bedrövelser. Det är inte heller omöjligt att Røed Larsens argumentation går att överföra på pensionsreformen. Folk litade på politikerna och accepterade därför att oljan inte användes till att rädda den välfärd de bespetsat sig på. Men problemets struktur är ändå annorlunda. Det är en sak att inte kräva mer och bättre i vetskap om att den som gapar efter mycket ofta mister hela stycket, en annan att gå med på åtstramningar i frånvaro av kris och i det skarpa skenet av ett enormt överföd. Därtill skall läggas att pensionsreformen planerades under en period när oljefondens tillväxt överträffade experternas mest optimistiska prognoser. 
Även om den nya välfärdslitteraturen i huvudsak utgår från en krisoch-nödvändighet-tematik är den inte befriad från resonemang om betydelsen av fonderat kapital. John Myles och Paul Pierson har exempelvis visat att länder som Sverige och Kanada, som byggt upp betydande buffertfonder i anslutning till det gamla systemet, förfogade över en bredare reformrepertoar än länder utan motsvarande tillgångar. Inte minst underlättade fondkapitalet övergången från det gamla systemet till det nya, bland annat genom att undanta de äldre generationerna från reformens konsekvenser eller intentioner (Myles \& Pierson 200I). I Sverige har buffertfonden (om än i nedsmält form) fortfarande en viss funktion i och med att den är tänkt att balansera tillfälliga obalanser mellan utgifter och inkomster (Sundén 1998). Liknande lösningar finns inbyggda i det nya norska systemet men därmed inte sagt att Myles och Piersons analys utan vidare går att tillämpa på norska förhållanden. Medan de svenska och kanadensiska buffertfonderna är direkt baserade på pensionsavgifter, och knappast tillförs nytt kapital, baseras den norska på oljeinkomster och förväntas växa under de kommande decennierna.

I så måtto stod de norska reformatörerna inför ett helt nytt problem $\mathrm{i}$ förhållande till både samhällsforskarnas välfärdsanalyser och ekonomernas oljeanalyser - ett slags ofrivillig valfrihet. Enkelt uttryckt aktualiserade pensionsfrågan i en mycket vardaglig mening frågan vad oljepengarna egentligen skulle användas till.

\section{Svensk exkurs - pensionsreformer som krispolitik}

Hur uppstår behovet av reform? Här är det belysande att jämföra Sverige och Norge - Sverige får representera ett europeiskt typfall såväl som särfall. Den svenska reformen delar denna egenskap med alla andra reformer - något alltigenom generaliserbart exempel torde inte existera. I någon utsträckning är varje reform unik, följer sina egna upptrampade institutionella spår, är förankrad i sin egen politiska kultur, svarar mot sina egna majoritetsförhållanden och partipolitiska konfigurationer (Lundberg, Kangas \& Ploug 20Io). Det som gör Sverige intressant i sammanhanget är att de norska reformatörerna i så hög grad tycks bygga vidare på den svenska erfarenheten (Marier 20I4). Detta kan verka naturligt 
med tanke på vårt gemensamma politiska och institutionella arv, men i själva verket är sidoblickarna på Sverige ett besynnerligt drag i den norska reformen. Omständigheterna kunde inte ha varit mer olikartade (Sejersted 2005, s. 418).

Den svenska pensionsreformen är oupplösligt förenad med kristendenserna i svensk ekonomi från 1970-talet och framåt, med vikande tillväxttal, ihållande arbetslöshet, hög inflation och inflationsbekämpning (Lindvall 2006). De strukturella problemen innebar att hela systemet för politisk problemlösning som byggts upp under efterkrigstiden sattes under extrem press. Socialdemokratin, som försett välfärdsstaten med ideologisk energi, försvagades (Östberg \& Andersson 2013). Arbetsgivarna lämnade kollektivavtalsmodellen och ett internationaliserat nyliberalt paradigm övertog tolkningsföreträdet i debatten om välfärdspolitikens inriktning (Andersson 2006; Ryner 2002).

Den svenska reformprocessen genomgick en rad distinkta faser. I en första omgång, som inleddes i början av 1980-talet, handlade det om direkta besparingar i det befintliga systemet, vilket vållade åtskilliga kontroverser. I en andra omgång, som inleddes under andra halvan av samma decennium, sattes det befintliga systemets interna problem och karaktär av belastning på budgeten i övrigt in i ett långsiktigt perspektiv av demografiskt åldrande och global konkurrens. 1984 tillsattes en stor utredning som samlade företrädare för alla berörda parter - partierna, pensionärerna, arbetsmarknaden, myndigheter - men trots att utredningen arbetade i sju år blev resultatet mycket påvert. Känslan av kris förstärktes, men också känslan av att lösningen var mycket avlägsen. Ett viktigt skäl till detta var ATP-systemets status som juvelen i den svenska välfärdskronan och en bärande balk i socialdemokratins historiska identitet som ett radikalt reformparti (Lundberg 2003; Lundberg, Kangas \& Ploug 2010).

Det var först när krisen på allvar nådde Sverige i samband med den borgerliga valsegern I99I som policyfönstret öppnades på glänt. För att överbrygga de politiska låsningarna var politikerna emellertid tvungna att skapa en originell reformväg som utestängde både pensionärsorganisationerna och arbetsmarknadens parter. När en ny utredning tillsattes hösten I99I fick endast partierna delta, och detta med endast en representant vardera (Socialdemokraterna hade två). Frågan stängdes alltså in 
i en liten grupp politiker som dessutom fick ett relativt öppet mandat att nå fram till en varaktig lösning (se också Marier 2008). Ett avgörande villkor var att det skulle gå fort. Alla inblandade utgick från att policyfönstret kunde blåsa igen närsomhelst. Redan efter ett år presenterades ett första förslag som innehöll de flesta väsentliga komponenterna och våren 1994 antog riksdagen riktlinjerna för ett nytt pensionssystem med bred majoritet. Därmed hann inte heller väljarna säga sin mening.

Det finns goda skäl att understryka det anmärkningsvärda i detta tillvägagångssätt (Lundberg 2003). Pensionsfrågan var inte vilken fråga som helst i svensk politik. Den hade definierat det politiska landskapet under större delen av efterkrigstiden och utgjorde en väsentlig ingrediens i socialdemokraternas anspråk på politisk makt. $\mathrm{Nu}$ avfördes den från dagordningen helt och hållet. Avpolitiseringen stadfästes ytterligare under arbetet med att omsätta principiella riktlinjer till konkret lagtext, när den så kallade pensionsarbetsgruppen krymptes ned till de fem partier som ställde sig bakom det ursprungliga förslaget. Detta kunde ske trots att nya och avgörande beståndsdelar tillkom i detta sena skede mest märkbart lagen om automatiskt balansering som säkerställer systemets finansiella soliditet i tider av akuta underskott (Lundberg 2003). ${ }^{27}$

Pensionsarbetsgruppen är i sig en märklig företeelse. När det nya systemet trädde i kraft 200I beviljade den sig själv ett slags semikonstitutionell status som yttersta garant för dess fortsatta integritet. Inga nya partier bjuds in att delta i gruppens möten. Diskussionerna skall vara helt interna och protokollförs inte på samma sätt som gängse utskottsarbete i riksdagen. Därmed sätts offentlighetsprincipen ur spel. De interna beslutsreglerna har hämtats från FN:s säkerhetsråd. Samtliga medlemmar har vetorätt i alla frågor som diskuteras. Sedan december 20I4 deltar även Miljöpartiet i gruppens möten, men medlemskapet gäller bara så länge som partiet sitter i regeringen. Partiets representant saknar dessutom vetorätt. ${ }^{28}$

27. Under arbetet med att omvandla det ursprungliga riksdagsbeslutet till ett fungerande system gick pensionsarbetsgruppen under namnet implementeringsgruppen.

28. Miljöpartiets medverkan i pensionsarbetsgruppen regleras inom ramen för decemberöverenskommelsen kring Sveriges politiska styrbarhet, som träffades mellan regeringen och fyra av sex av riksdagens oppositionspartier den 27 december 20I4. För beskrivning och välgrundad kritisk kommentar, se Joel Dahlberg, "Nonsens om pensionerna", Svenska Dagbladet, 28 december 2014. 
Även reformens utformning bär tydliga spår av denna ambition att skapa ett autonomt och självreglerande system. Målet var att isolera pensionssystemet från budgeten i övrigt. Pensionerna skulle vara självfinansierade. Det skulle vara raka rör mellan intäkter och utgifter - systemet skulle aldrig gå med underskott eller dra på sig skulder för efterkommande generationer att betala. För att lösa denna uppgift användes en rad snillrika metoder som i dag blivit vanliga i den internationella pensionsdiskussionen: avgiftsbestämning, livstidsinkomst, delningstal och automatisk balansering samt en gradvis utfasning av de pensionsrättigheter som tjänats in inom ramen för det gamla systemets ram. Resultatet blev en originell och förebildlig lösning. Visst fanns inspirationskällor, bland annat det italienska systemet. Men i få länder har man gått så systematiskt och renlärigt tillväga som i Sverige (Lundberg 2003).

Reformens strikt ideologiska inslag är snarast kopplade till premiepensionen, som innebär att en mindre del av pensionsavgiften förs över till ett separat fonderat system där individen genom statens försorg ges möjlighet att på egen hand välja mellan ett stort antal sparformer som privata aktörer erbjuder. Detta inslag i det svenska systemet har tilldragit sig mindre intresse i den internationella policydebatten. Dels eftersom det fungerat mindre väl - sedan det lanserades 200 I har aktivitetsgraden i premiepensionen minskat radikalt. Dels eftersom konstruktionen med individuella konton visat sig svår att rättfärdiga med rationella argument (Vägval för premiepensionen 2013). Fonderingen i sig är inte problemet, utan snarare den hårt drivna individualiseringen och överdrivna tilltron till medborgarnas "finansiella läskunnighet" (financial literacy) (Belfrage 2007). ${ }^{29}$ Andra kritiska synpunkter är att de administrativa kostnaderna blir oförsvarligt höga och att pensionsavgifterna hamnar i fel fickor (Vägval för premiepensionen 2013).

29. Av de individer som träder in i systemet är det få som utnyttjar sina valmöjligheter - merparten hamnar i icke-väljarfonden - och av dem som väljer en första gång är det sedan få som sedan gör ett nytt val. Mot denna bakgrund frågar sig till och med pensionsarbetsgruppens egen utredare om det är försvarbart för staten att administrera en form av valfrihet som nästan ingen utnyttjar. Vägval för premiepensionen 2013. 


\section{Medborgaren som pensionsentreprenör}

Sammantaget innebär det svenska systemets uppbyggnad en långtgående individualisering av pensionerna. Riskerna bärs av den enskilde i stället för av samhället. En annan konsekvens är att pensionen förvandlas till ett livsprojekt och att medborgarna uppmanas att inta ett "entreprenöriellt" förhållningssätt till sina egna livslopp (Nyqvist 2008). Med detta avses att pensionen inte kompenserar för klass, kön, etc. utifrån en universell medborgarskapstanke, utan avspeglar det liv man levt utifrån en försäkringsmässig rationalitet. Pension blir en fråga om planering och kalkylerat risktagande. Även själva rättvisan - den rättvisa som systemet gör anspråk på - har genomgått en förskjutning: från substantiell rättvisa till procedurell rättvisa (Lundberg 2003). Som medborgare kan man inte klaga på sin pension i efterhand. I stället får man rannsaka sig själv och sina livsval. Skulle man verkligen ha gjort den där backpackerresan till Asien i sin ungdom, skulle man ha stannat hemma med sina barn när de var små, skulle man ha skrivit en självförverkligande avhandling i teatervetenskap i stället för att satsa på ett riktigt jobb med goda karriärmöjligheter? Framför allt: Skulle man ha förträngt sin stundande ålderdom? (Lundberg 20I2.)

Självfallet är det för tidigt att uttala sig om vad denna förskjutning innebär för medborgarnas pensioner. ${ }^{30} \mathrm{I}$ mångt och mycket är det en fråga om i vilken grad medborgarna internaliserar det nya systemets rättvisesyn och det ökade personliga ansvaret. Häri ligger utmaningen för politikerna. Orkar de leva med konsekvenserna, till exempel ökad ojämlikhet i pensionärskollektivet eller ökad fattigdom i den äldre befolkningen? Kan de tygla sina impulser att korrigera och ställa till rätta eller faller de till föga när kritiken växer och klagomålen formerar sig till politiska subjekt? (Forslund 2007.) $)^{31}$

30. Det saknas dock inte försök att uppskatta framtidens pensionsnivåer och vad systemet kommer innebära för olika befolkningsgrupper. Se till exempel Flood 2007.

3 I. Det har redan börjat mullra i pensionärsleden. 20II presenterade Sveriges fem rikstäckande pensionärsorganisationer en kritisk rapport som yrkade på tillsättandet av en parlamentarisk utredning med uppdrag att ta fram förslag om både akuta och långsiktiga åtgärder (Pensionssystemet, blev det som tänkt? Vad behöver göras? 20II). Sedan dess har kritiken knappast minskat i styrka. 


\section{Pensionsreformer av tredje graden}

Den svenska pensionsreformen är unik i många avseenden, både i ett nordiskt och i ett internationellt sammanhang. Vid sidan av Sverige har få länder nått upp till en reform av tredje graden i Peter Halls välkända schema över institutionell förändring, ett ingrepp som är så genomgripande att det nära nog svarar mot ett paradigmskifte i Thomas Kuhns mening (Hall 1993). I realiteten har de flesta länder nöjt sig med att på olika sätt bygga vidare på gamla lösningar, vad Peter Hall i sin artikel kallar reformer av första och andra graden.

Halls schema har mycket som talar för sig. Ett problem är dock att han underskattar betydelsen av gradvis förändring och till synes obetydliga åtgärder (Lundberg, Kangas \& Plough 20ıO). Jacob S. Hacker å sin sida skiljer mellan driva (drift), skikta (layering) och omvandla (conversion), vilket är ett rimligare sätt att klassificera vår tids pensionsreformer. Med "driva" avses att ett system bevaras men att de sociala riskernas struktur förändras. Detta passar väl in på den danska reformprocessen som i mångt och mycket gick ut på att göra så lite som möjligt. "Skikta" innebär att nya lager läggs på ett gammalt system, "omvandla" att gamla regelverk tillämpas på nya sätt. Den gradvisa förändring av det finska pensionssystemet som inleddes under mitten av 1990-talet kan lite förenklat beskrivas som en blandning mellan skiktning och omvandling. Nya lager lades till de gamla samtidigt som gamla regelverk gavs ny tilllämpning (Hacker 2004). ${ }^{32}$

Enligt Hacker bör dessa tre former för smygande förändring ställas mot vad han kallar utesluta (elimination), att avskaffa gamla system och skapa nya (Hacker 2004). Det är aldrig lätt att karakterisera institutionell förändring men de flesta forskare är i dag tämligen överens om att den svenska reformen verkligen gick på djupet (Anderson \& Immergut 2007). Ett nytt system byggdes på ruinerna av det gamla. Det behöver inte innebära att varje enskild byggsten är ny. Roms många kyrkor och katedraler består till stor del av marmor från hedniska tempel. Men arki-

32. Se även Thelen 2003, Campbell 2004, samt Mahoney \& Thelen 20IO, för teoretiska modeller som utnyttjar en likartad begreppsapparat för att förstå hur komplexa institutioner förändras. 
tekturen är ny och byggherrarna bekänner sig till andra gudar. $\AA$ andra sidan, vilket ligger implicit i Hackers analys, finns det inget som säger att resultatet blev mer omstörtande i Sverige än i andra länder. Som Olli Kangas och Karl Hinrichs framhåller kan många små och obetydliga reformer få stora konsekvenser, likväl som en genomgripande reform kan passera mer eller mindre obemärkt (Hinrichs \& Kangas 2003). Uteslutning förutsätter inte ens att målet i Sverige var särdeles djärvt formulerat. Drivande var snarare historien och ATP-systemets status som identitetsmarkör och demarkationslinje mellan partierna. Eftersom pensionssystemet var så politiserat som det var krävdes en remarkabel politisk lösning som i stor hast beslutades och implementerades i likaledes remarkabla former (Lundberg 2009).

Pensionsarbetsgruppens egenartade ställning är ett utmärkt exempel på detta. Dess arbetsformer, som i den offentliga retoriken förankras $\mathrm{i}$ en svensk tradition av breda kompromisser och social ingenjörskonst, är inte bara en garant för systemets långsiktiga bärkraft utan $i$ än högre grad ett slags exorcism som skall hindra det förflutnas andar från att hemsöka vår egen mer rationella samtid. Teknokrati ersätter politik och värderingar. Eventuella justeringar måste göras under kontrollerade former och får inte resultera i konflikter som spiller över i den offentliga debatten. Samtidigt, vilket måste poängteras, går inte detta tänkesätt att skilja från den krissituation som rådde i Sverige under 1990-talet (Lindh \& Lundberg 2008). Det var också så reformen rättfärdigades i sin samtid, som ett avgörande moment i en ekonomisk återhämtningsstrategi och som en revitalisering av den svenska modellen.

Med andra ord: det handlade inte bara om att lösa problem i pensionssystemet utan i lika hög grad om att med en pensionsreform lösa problem i den vidare ekonomin (Lundberg 2003).

\section{Norsk exkurs - pensionsreformer som överflödspolitik}

Som kontrast har den norska reformen, som tycks följa den svenska en god bit på väg, förhandlats fram under sällsynt gott väder. Problemen, såsom de beskrivs i utredningar och beslutsunderlag, är uteslutande förlagda till en avlägsen framtid som endast är tillgänglig för de experter 
som behärskar avancerad statistik och ekonometri. Egentligen borde inte detta räcka för att driva fram en genomgripande reform, det visar om inte annat en generell västerländsk erfarenhet. Politikerna borde huka i skyttegravarna. Riktigt så enkelt är det förstås inte heller. Även Norge står inför ett åldrande som innebär ökad belastning på de offentliga finanserna. Men åldrandets samtidspolitiska relevans är inte entydig. Om det skall vinna styrka i debatten och fånga politikernas sinnen måste det på ett eller annat sätt kopplas till mer omedelbara och begripliga problem. Här bör man i stället titta på två andra faktorer.

För det första normaliseringskravet, det vill säga den upplevda kostnaden för att inte göra som alla andra. Ser man till den statistik som presenteras i diverse beslutsunderlag är denna fråga mycket närvarande. ${ }^{33}$ Budskapet tycks vara att Norge inte kan vara det enda västland som inte reformerar sina tunga välfärdssystem. För det andra rädslan för att aktivera naturresursförbannelsen. Inte heller på denna punkt är beslutsunderlaget entydigt. Även om oljepengarna mycket väl kunde ha ingått $\mathrm{i}$ en lösning som innebar modifikationer i det befintliga systemet (vad Hacker definierar som att skikta och att omvandla) prövades aldrig detta alternativ. Politikerna ville till varje pris undvika att normaliseringskraven nådde fram till en punkt där oljan gjorde entré i välfärdsdebatten på allvar. Därmed blev inte heller passivitet ett realistiskt perspektiv. Med tanke på oljepengarnas sociala dimension skulle det i förlängningen ha varit omöjligt att endast urholka det gamla systemet. Fokus skulle obönhörligen hamna på kallsinniga politiker som undlåter att handla trots att resurserna bevisligen finns där.

Någonstans på vägen trädde alltså avskaffande fram som ett rimligt alternativ. Ett nytt system som svarade mot en ny situation, inte en svensk situation med ekonomisk kris och stukat nationell självförtroende, utan en situation där oljan och välfärden (som etablerats som två skilda politikområden) på sikt riskerade att invadera och slutligen förinta varandra.

33. Se till exempel hur tabeller byggs upp och kommenteras i långtidsutredningen 2002-2005, som lade fram en ursprunglig och auktoriserad argumentation för behovet av en strukturell pensionsreform. St. meld. nr. 30 (2000-200I), s. 465-494. 


\section{"Det här är ingen jävla leksak"}

Det finns en rolig scen i komedin 40-year-old virgin där Steve Carells rollfigur Andy och hans flickvän Trish, spelad av Catherine Keener, tumlar runt på sängen i hans lägenhet. Som filmtiteln antyder är det en nyckelscen, vilket också märks på Andys nervösa uppträdande. Efter många om och men är det nu det skall ske. Den abnorme Andy skall äntligen initieras och normaliseras - bli som alla andra. Problemet är att de i hettan råkar rulla in över hans betydande samling av actionfigurer $\mathrm{i}$ obrutna förpackningar, som filmen igenom fătt symbolisera hans uppskjutna vuxenblivande och inverterade karaktärsmoral.

Förtrollningen bryts på ett ögonblick. Andy flyger upp ur sängen och börjar omedelbart plocka bland sina actionfigurer samtidigt som han babblar nervöst om hur viktigt det är att bevara förpackningarnas integritet. Uppträdet får Trish att tappa tålamodet: "Jag kastar mig över dig och det enda du tänker på är några jävla leksaker.” Men Andy låter sig inte bevekas.

De är inga jävla leksaker. Det här är Iron Man. Fattar du? Jag fick den här när jag gick i lågstadiet. Vet du hur svårt det är för en liten unge att låta bli att öppna den?

En scen ur en amerikansk komedi sammanfattar naturligtvis inte norska politikers förhållande till oljerikedomarna. Men visst finns det en familjelikhet? Smärtpunkten eller den uppdämda aggressionen är densamma: svårigheten att inte ge efter för sina impulser, att inte låta sig hänföras av ögonblickets möjligheter, att inte handla kortsiktigt i nuet utan tanke på ett värre ont i det långa loppet. Vi vet inte hur Andy bar sig åt för att besegra sina egna passioner, men litteraturen rymmer många hjältar som misstrott sina själsliga egenskaper och på olika sätt försökt tygla sitt handlande. Mest känd är förstås Odysseus som under sin hemfärd från Troja surrade fast sig vid masten för att inte falla för sirenernas locktoner. ${ }^{34}$

34. Ett annat klassiskt exempel är conquistadoren Hernán Cortés, som uppmanade sina män att bränna alla skepp när de landsteg på Yucatáns stränder. När de stod inför aztekernas trupper skulle det inte finnas utrymme för feghet eller ånger, slog han fast: "Om vi skall hem, kommer vi hem i deras skepp." 
Kring detta så kallade tidskonsistensproblem har det vuxit fram en policyinriktad samhällsteori som fångar in hur norska politiker närmade sig ekvationen kring olja och välfärd, och som dessutom sprider ljus över hur beslutsprocessen strukturerades (Elster 1979; Elster 2000). Man kan tala om tre steg. Först skulle oljeintäkterna ytterligare isoleras från statsbudgeten, sedan skulle pensionerna isoleras från oljan. Det tredje steget, att isolera pensionerna från statsbudgeten, orkade man, av skäl som jag kommer in på senare, inte med. Huvudmålet tycks dock ha varit att skapa ett pensionssystem som inte är beroende av oljeintäkterna och som kan bära sina egna kostnader i den avlägsna oljelösa framtid som ytterst motiverade reformen som sådan. Här är det uppenbart att de norska reformatörerna på många sätt följde de svenska i spåren, trots att de började på en annan plats och slutade på ett annat ställe.

I allmänna termer refererar tidskonsistens till vår mänskliga benägenhet att ångra våra handlingar och beslut (Schelling 1978). Om man dröjer vid Andys exempel och undersöker vad Iron Man i skrivande stund betingar för priser på Ebay uppgår skillnaderna mellan använda och oanvända exemplar till hundratals, ofta tusentals kronor. Ö̈ppnade förpackningar av äldre utgåvor ligger regelmässigt på tusentals kronor medan använda exemplar, som i värsta fall saknar vitala delar, säljs till överkomliga priser. Här finns alltså goda pengar att tjäna för barn som likt fiktionens Andy förmår att behärska sina omedelbara och primitiva lekimpulser.

Frågan är bara hur. Den dominerande uppfattningen bland ekonomer är att tidskonsistensproblemen kräver att man binder sitt framtida handlande med hjälp av oberoende institutioner och diverse automatiserade lösningar. ${ }^{35}$ En möjlighet är att låsa in actionfigurerna i ett bankfack och ge nyckeln till sina föräldrar, en annan att skapa något slags beslutsnorm - exempelvis att ens veckopeng dras in om man öppnar förpackningen eller att man ger sig själv en belöning för varje år som

35. Som ekonomen Aanund Hylland påpekat bör man förstås tillfoga att det i politiska sammanhang som regel inte handlar om att binda sig själv utan om att binda framtida majoriteters handlande (Hylland 2005, s. I83): "De som binder, og de som blir bundet, er vanligvis ikke de samme personene, selv om noen kan høre til begge grupper." 
förpackningen förblir obruten. ${ }^{36}$ Enkelt uttryckt är syftet med institutionaliserade normer att begränsa sina möjligheter att handla kortsiktigt, ogenomtänkt och irrationellt. Det må handla om benägenheten att tillfredsställa uppretade välfärdsopinioner med sockrade vallöften eller något annat (Kydland \& Prescott 1977)..$^{37}$

Tidskonsistensproblemet präglar alla politikområden som rör framtiden och har de senaste decennierna gett upphov till nya politiska metoder. Penningpolitiken, som tidigare var politikernas ansvar, har i många länder delegerats till en oberoende riksbank. En annan metod är att låta budgetpolitiken begränsas av ett utgiftstak som alla partier i parlamentet förbinder sig att upprätthålla. Det återspeglas även i svenska politikers ambition att skapa ett pensionssystem som är autonomt och självreglerande i förhållande till statsbudgeten och inte förutsätter politiska brandkårsutryckningar. Det mest slående uttrycket för denna ambition är den automatiska balanseringen av ålderspensionen (bromsen) som skriver ned pensionsbeloppen i tider av stigande utgifter utan att beslutsfattarna behöver utsätta sig för några onödiga risker. Även i övrigt innehåller det svenska systemet många exempel på så kallad automatisk politik, det vill säga att ansvaret för potentiellt impopulära åtgärder antingen regleras $\mathrm{i}$ lag eller överförs till autonoma institutioner eller oberoende expertgrupper (Lindh \& Lundberg 2008; Lundberg 2003).

Det finns ingen anledning att avfärda denna trend med hänvisning till fega och illvilliga politiker. Bindningsstrategierna har växt fram ur de verkliga problem som infinner sig när kontroversiella och långsiktiga beslut måste fattas i ett demokratiskt sammanhang (Brooks \& Weaver 2006). Beträffande den svenska pensionsreformen var det exempelvis uppenbart för alla inblandade parter att det gamla ATP-systemet saknade finansiell bärkraft. De demografiska kurvorna pekade i ogynnsam

36. Så här lyder Schellings klassiska ämnesintroduktion (I978, s. 290): ”Vi är många som har små knep vi tar till för att få oss själva att göra det vi borde göra eller inte göra det vi borde låta bli. Ibland flyttar vi saker utom räckhåll i frestelsens ögonblick, ibland lovar vi oss själva små belöningar och ibland lämnar vi över makten till en pålitlig vän som får övervaka våra kalorier eller våra cigarretter. Vi ställer väckarklockan $\mathrm{i}$ andra änden av rummet så att vi inte kan stänga av den utan att gå ur sängen. Folk som ständigt kommer för sent ställer fram klockan några minuter för att lura sig själva.”

37. Se även Lindh \& Lundberg 2008, för en översikt som dessutom är kopplad till den svenska pensionsreformen. 
riktning och systemets tekniska uppbyggnad skapade en bakvänd relation mellan avgifter och utgifter. Samtidigt hade både socialdemokrater och borgerliga politiker investerat åtskillig politisk prestige i sina historiska positioner, antingen de i möjligaste mån ville bevara det gamla systemet eller skrota det helt och hållet (Lindh \& Lundberg 2008).

\section{Ett naturligt äktenskap}

Oljan var inte heller någon leksak. Bara upprättandet av oljefonden 1990 var ett försök att "underbygge de langsiktige hensyn ved anvendelse av petroleumsinntektene", som det hette i lagtexten (Lov om Statens Petroleumsfond, 22 juni 1990). Samtidigt vill jag betona att försöken att minimera oljans skadliga effekter inte besvarade frågan om hur man skulle använda de tillgångar den genererade.

Det är skillnad mellan ett system för utbetalningar och ett system som kanaliserar en kontinuerlig värdeomvandling från naturresurs till reda pengar. Tillgångarna samlas på hög, men för vilket ändamål? Det regelverk som sattes upp när oljefonden skapades I990 innebar inte heller någon egentlig garanti mot överutnyttjande, varken på kort eller på lång sikt. Ambitionen var i första hand att förhindra politiskt taktiserande och synliggöra uppenbart missbruk. Det är här pensionerna som en framtida utgiftspost kommer in. Redan i början av 1990-talet gjorde sig tanken gällande att oljepengarna skulle kunna täcka de ökade kostnader som befolkningens åldrande medförde. Som ekonomen Øystein Olsen konstaterade i ett föredrag på Sosialøkonomisk Forenings konjunkturseminarium i september 1995 var grundproblemet ungefär detsamma i alla västländer - om inte annat hade det fătt en pregnant beskrivning $\mathrm{i}$ Världsbankens rapport Averting the old age crisis 1994 - men dess struktur var helt annorlunda i Norge (Världsbanken 1994). Utgångsläget var bättre, som han uttryckte det (Olsen I995):

For det første er statens finansielle formueposisjon i utgangspunktet god. For det andre gir den anslått sterke økningen i petroleumsinntektene de nærmeste 5-IO årene Norge en særlig god anledning til å gjennomføre en ytterligere styrking av offentlige finanser. ${ }^{38}$

38. Den r januari 201 u utnämndes Olsen till chef för Norges centralbank. 
Den dåvarande regeringen ställde sig dock skeptisk till att knyta oljefonden till de förväntade utgiftsökningarna i folketrygden. Risken var att detta skulle uppfattas som att oljan öronmärktes för framtida pensionsutbetalningar, vilket regeringen av olika skäl ville undvika. Dels skulle budgetpolitiken hamna under extrem press, inte minst eftersom statens utgifter för medborgarnas pensioner till stor del är lagfästa. Dels skulle en fonduppbyggnad i denna föregripande anda ge intrycket att pensionsutgifterna hade en särställning i statsbudgeten, något som stred mot principen om en enhetlig och allsidig behandling av statens olika utgiftsområden. En annan farhåga var att man invaggades i falsk säkerhet och i ett senare skede fallerade $\mathrm{i}$ arbetet med att föregripa framtida obalanser i de offentliga finanserna (Cappelen 2002).

Frågan bet sig fast i debatten. Mot slutet av 1990-talet tillsatte regeringen en offentlig utredning med uppdrag att förbereda en eventuell fondering av folketrygden. Någon pensionsberedning av svenskt slag var det inte tal om - direktiven snävades in till systemets finansieringssida. Därmed inte sagt att frågeställningen var oskyldig. Genom att fokusera på finansiella aspekter satte man oljeproblematiken tydligt i fokus. Med andra ord: här fanns ett problem i vardande, en förväntad kostnadsökning i samband med befolkningens åldrande, men också ett ständigt växande kapital. Kunde man tänka sig en sammankoppling? (NOU I998:IO.)

Utredarna laborerade med fyra referensmodeller. Den första modellen utgick från en vidarebefordring av 1990 års modell med generellt sparande i statligt regi - en modell som placerade politikerna och tjänstemännen på finansdepartementet i främsta rummet. Den andra modellen var upprättandet av en statlig pensionsfond. Då kom oljan längre ifrån politiken men farligt nära pensionerna. Modell tre var en avgiftsbaserad privat pensionsfond och modell fyra en privat pensionsfond med investeringsval (ungefär som premiepensionen i Sverige). I de senare modellerna blev pensionerna i högre grad medborgarnas eget ansvar med förbehållet att varje avsteg från det rådande pay as you go-systemet representerade en kostnad för övergångsgenerationen, vars pension måste finansieras två gånger (NOU I998:IO).

Läsningen är knappast hisnande. $\AA$ andra sidan anas oljans politiska explosivitet mellan raderna. Enkelt uttryckt kan man säga att den 
rätta typen av strukturell begränsning inte ville infinna sig. Ekonomin var god, värdeomvandlingen genererade överskott, med följd att frågan om vilken referensmodell som var att föredra förblev en politisk fråga. Utmaningar saknades inte men framtiden var fortsatt formbar en arena för ideologisk diskussion. Kort sagt kunde man göra ungefär som man ville. Man kunde fortsätta i upptrampade spår, man kunde samla i ladorna, pensionerna kunde fredas, oljan kunde öronmärkas. Man kunde också tänka sig en helt ny, liberaliserad folketrygd. Handlingsrepertoarens vidd blir mest slående i diskussionen av alternativ tre och fyra, där utredarna konstaterade att double payment-problemet, som normalt anses stå i vägen för en övergång till ett alltigenom fonderat pensionssystem, inte var giltigt för Norge. Pengarna skulle räcka till det också (NOU I998:I0)..$^{39}$

Inför denna ohyggliga valfrihet ryggade utredarna tillbaka. Inga konkreta förslag presenterades, ehuru slutdiskussionen, förmodligen under finansdepartementets inflytande, vittnar om en förkärlek för den första referensmodellen som bevarade ett mått av frihet i hur oljepengarna kunde användas (NOU 1998:IO). En rimlig tolkning av utredningens resultat är annars att den delvis desarmerade den alarmerande framtid som var kopplad till befolkningens åldrande, men därigenom skapade scenarier där oljan på olika sätt sipprade in i välfärden som framstod som väl så hotfulla. Här fanns oljeprisernas volatilitet, här fanns naturförbannelsen, här fanns överflödets paradox, här fanns oljans ändlighet och frågan om hur Norge som nation skulle stå sig när det sista oljefatet skeppats ut på världsmarknaden. Man kan också peka på att graden av handlingsfrihet tycks förbunden med en närmast existentiell oro, en benägenhet att gripa efter "en lag som andra stiftat" i stället för att träda fram som "sin egen lagstiftare"..$^{\circ}$

39. För en teoretisk och empirisk introduktion till double payment-problemet, se Myles \& Pierson 200I, s. 313.

40. Begreppsparet har lånats av Immanuel Kant som i sin Grundläggning av sedernas metafysik talar om viljans "heteronomi" (Kant 1997 [I785]). Det bör understrykas att Kant såg den fria viljan som en förmåga att lyda förnuftet, en sträng definition som de norska reformatörerna sannolikt skulle sluta upp bakom. Se vidare Ekenberg 2012. 


\section{Handlingsregeln}

Detta var denna hotbild som blev vägledande. Oljan kunde rädda pensionerna, pensionerna kunde ge oljan mål och mening. Men detta på ytan naturliga äktenskap mellan förväntade inkomstökningar och utgiftsökningar kunde också få katastrofala följder. Regeringens långtidsprogram 2002-2005 var helt impregnerat av denna gråtrista esprit de sérieux, som Jean-Paul Sartre kallar det när man låter sina projekt bestämmas av omgivningen och inte den egna friheten (Sartre 1976 [1943], s. 75). Det är bra nu, men det blir värre i morgon; eller: nu är det tyst och stilla men i morgon når vi fram till sirenernas Anthemoessa och då måste vi vara ordentligt fastsurrade vid masten. Eller: varför leka med vår Iron Man nu och riskera att tappa bort hans löstagbara shatter blaster när vi kan sälja honom i ursprungligt skick på Ebay om fyrtio år för flera tusen kronor? Eller: vi måste spara på våra krafter till i morgon när vi på allvar inleder den skarpa stigningen uppför den demografiska kurvan. Eller (St. meld. nr. 29 [2000-200I], s. 3):

Norsk økonomi har siden 1993 vært inne i en høykonjunktur. Sterk økonomisk oppgang førte til en situasjon med lite ledig kapasitet. Budsjettpolitikken ble strammet til for å motvirke en tiltakende pris- og kostnadsvekst. Samtidig står en overfor langsiktige utfordringer i budsjettpolitikken, fordi utgiftene til pensjoner, pleie og omsorg vil øke kraftig, samtidig som petroleumsinntektene vil avta.

Retoriken var allt annat än norsk. Man hittar den i vartenda västland. Men den avslutande strofen om oljan ger ändå tidskonsistensproblemet särskild valör. Stora utmaningar väntade runt hörnet, så var det förstås. Men hur ge trovärdighet åt dessa när tiderna var sällsynt goda? Än värre var frågan om kontinuitet. Låt vara att man litade på sin egen förmåga att försätta sig i ett tillstånd av sublim överhöghet, men kunde man lita på att ens kollegor (både samtida och framtida) skulle klara detsamma? För att citera James Madison (Madison, Hamilton \& Jay 1987 [I788], s. I25): "Upplysta statsmän kommer inte alltid att stå vid rodret." Och i ljuset av detta molande tvivel: Hur såg man på det demokratiska systemets långsiktiga förmåga att fatta kollektivt rationella beslut? 
Hur man än vände och vred på saken blev oljan ett problem. Lät man systemet driva - "vegringsalternativet" som långtidsutredningen kallade det - skulle välfärden dränkas i pengar. Den offentliga sysselsättningen skulle öka lavinartat och de sociala utgifterna skjuta i höjden. I framtiden, vilket i dessa sammanhang alltid betyder när oljan tagit slut, väntade ett bortskämt folk som vältrade sig i illusoriska rikedomar. Byggde man på nya lager - "referansealternativet" - och begränsade den offentliga sysselsättningens tillväxt samtidigt som delar av oljeintäkterna användes till att sänka skattenivåerna och bevara folketrygden mer eller mindre intakt, skulle resultatet bli hyfsat till en början. Sedan väntade dystrare tider. Från 2020 till 2040 skulle budgetunderskottet öka kraftigt som en följd av ökade pensionsutgifter och andra åldersrelaterade utgifter. Här kunde man ana en uppgift för oljefonden men till priset av att den tömdes på resurser (St. meld. nr. 30 [2000-200I]). Till detta kom de vanliga problemen: oljans ändlighet, prisvolatiliteten och snedvridningseffekterna: "Både våre egne og andre lands erfaringer viser at for sterk bruk av petroleumsinntekter kan gi store omstillingskostnader og ledighetsproblemer (hollandsk syke)" (St. meld. nr. 29 [2000-200I], s. 7). Som betonats fanns också ett principiellt motstånd mot att öronmärka oljepengarna för bestämda ändamål.

Lite i skymundan, men i direkt anslutning till långtidsutredningens arbete och med regeringens välsignelse, smiddes därför djupgående planer på en mer varaktig lösning som frikopplade oljefonden från de scenarier som långtidsutredningen tecknade, och framför allt frikopplade den från de förväntade utgiftsökningarna i pensionssystemet. ${ }^{4 \mathrm{r}}$ Förslaget presenterades i St. meld. nr. 29 (2000-200I) under den föga fantasieggande rubriken "Bruk av forventet realavkastning av Petroleumsfondet". Den enkla huvudpoängen var att tidskonsistensproblemet skulle hanteras med en jämn infasning av oljeintäkterna. Mer precist innebar detta att användningen av oljefonden för överskådlig framtid baserades $\mathrm{i}$ en "handlingsregel" som innebar att fondkapitalet gradvis fasades in $\mathrm{i}$ statsbudgeten i takt med utvecklingen i dess förväntade realavkastning. Det årliga gränsvärdet sattes till 4 procent av fondkapitalet (St. meld.

4I. Om spelet kring handlingsregeln, se Sandø 2013. 
nr. 29 [2000-200I]). Ett absolut tak för budgetarbetet som alla partier i Stortinget utom Sosialistisk Venstreparti och Fremskrittspartiet förband sig att respektera. ${ }^{42}$

Konstruktionen var snillrik. Handlingsregeln säkerställde att bruket av oljepengarna inte ökade exponentiellt i relation till förväntade utgiftsökningar. Pengarna skulle finnas där, som en absolut trygghet och ett kontinuerligt smörjmedel, men i själva budgetarbetet skulle de snarast få karaktären ett årligt bidrag från en godhjärtad onkel: ett välkommet tillskott men inget man kunde leva eller bygga sin framtid på. Inte heller skulle de stå i vägen för besparingar och effektiviseringar. En annan förtjänst var att oljefonden inte längre kunde öronmärkas för bestämda ändamål eller spenderas av en viss generation. Med detta blev handlingsregeln en varaktig lösning på de moraliska problem som är förenade med ändliga naturresurser. Oljefonden kunde ges evighetens prägel. Den skulle finnas kvar långt efter att borrhålen torkat ut och de internationella oljebolagen packat ihop sina plattformar.

Viktigare var att handlingsregeln befrämjade normaliseringslinjen, minskade den upplevda kostnaden av att inte vara som alla andra. Politiken kunde styras in mot den europeiska mittfåran: "I en stadig tettere integrert verden reduseres dessuten mulighetene for å ha et skatte- og avgiftsnivå som avviker mye fra andre land" (St. meld. nr. 29 [2000200I], s. 7-8). Inte ens handlingsregeln löste egentligen det norska kostnadsproblemet men den skärpte ramarna och skänkte ett mått av trovärdighet åt den gängse transnationella terminologin kring framtida utmaningar och nödvändiga begränsningar (Watson \& Hay 2003). Även i Norge blev det nu möjligt att blanda färgerna och ge världen en betryggande gråskala, för att återknyta till Hegel. Norge skulle inte längre vara utestängt från den "bestämda kunskap" om "förhandenvarande omstän-

42. Bägge partierna har dock skiftat hållning i frågan. Sosialistisk Venstreparti skrev under på handlingsregeln när de upptogs i Stoltenbergs regering 2005. Fremskrittspartiet gjorde detsamma i samband med regeringsskiftet 2015. Hållningslösheten inför utsikterna till makt är inte ägnad att förvåna. Fenomenet noterades redan av Machiavelli (200I [I53I], s. 23I): "Och enär detta är något som hänt många män och vid många tillfällen, har därav uppstått ett ordspråk som säger 'Han har en åsikt på torget och en annan i palatset'." 
digheter och förhållanden" som utmärkte det rådande "intellektuella kungadömet”. Man kunde dölja sig bakom samma gravallvar som andra. Helt klart var i alla fall att med oljepengarna förseglade i en obruten förpackning blev det äntligen tal om att inleda arbetet med en ordentlig pensionsreform.

\section{Från jämlikhet till frihet}

Här måste man stanna upp ett ögonblick, eller till och med ta ett steg tillbaka. Både handlingsregeln och planerna på en pensionsreform kan ses som integrerade moment i en mer allmän omstrukturering av den norska välfärdsstaten (Sejersted 2005, s. 445-446). 2002 genomdrevs en stor sjukvårdsreform som innebar att sjukhusen och specialistvården ombildades till halvprivata hälsoföretag som sorterar under fem administrativa sjukvårdsregioner under regeringens kontroll (Angell 2012; Hagen \& Kaarbøe 2006). Här finns inte skäl att gå djupare in i denna reform, som i sin iver att på samma gång centralisera och decentralisera komplexa institutioner tycks skapa sin alldeles egen problemvärld (Lægreid, Opedal \& Stigen 2005). Men beröringspunkterna med pensionsreformen är påtagliga.

I bakgrunden spökade rädslan för åldrandets effekter och en situation där på sikt radikalt ökade sjukvårdskostnader måste finansieras med på sikt radikalt avtagande oljeintäkter. Ett annat led i omställningen var att etablera ett mera strängt finanspolitiskt ramverk, bland annat genom att överlåta delar av penningpolitiken på en oberoende riksbank - en åtgärd som presenterades i samma betänkande som lanserade handlingsregeln. Det finns förstås många sätt att tematisera innebörden av denna styrningsideologi. New public management är en bred internationell trend med många ansikten (Pollitt \& Bouckaert 2004). Här ryms faktiska problem, som köbildning, bristande effektivitet och en förändrad kravbild. Men också frågor om ideologi, maktförhållanden och värderingsförskjutningar. Francis Sejersted talar i sin bok om socialdemokratins tidsålder om att både Sverige och Norge de senaste decennierna övergått "från en princip om största möjliga jämlikhet till en princip om största möjliga frihet - valfrihet" (Sejersted 2005, s. 445). 
Socialisternas jämlikhet i resultat byts ut mot liberalernas jämlikhet i frihet. ${ }^{43}$

En annan fråga är vad detta skifte innebär i djupare mening. Den brittiske samhällsteoretikern Nikolas Rose, som behandlat vår tids frihetstänkande i flera böcker, framhäver särskilt de förändrade relationerna mellan stat och individ (Rose 1999, s. 139). Grundtanken är enkel. För att staten skall styra bättre måste den styra mindre - huvuduppgiften är att jämna ut spelfältet, att upprätta tydliga ramverk som alla individer får förhålla sig till på likartade sätt. Ansvaret för trygghet och välstånd, å sin sida, överlåts på den enskilde individen. I någon mån är det väl endast mot bakgrund av detta tänkande som man kan förstå hur offentliga sjukhus kan förvandlas till företag, hur medborgarna kan bli kunder på en marknad och den offentliga servicens kvalitet kan bli den enskilde individens ansvar. Om bara individen axlar ansvaret för vardagslivets risker och realiteter och lär sig att orientera sig bland olika välfärds- och omsorgsproducenter, kan staten träda in i en övervakande roll som passar den betydligt bättre (Rose 1999, s. I39).

\section{Pensionsreformen blir tvingande nödvändighet}

Pensionsreformen var alltså ingen ensam satellit som färdades genom ett tyngdlöst universum. Den måste ses i sammanhang med både en bred för att inte säga jämntjock internationell trend på finans- och förvaltningspolitikens område och en alltigenom nationell norsk strategi för att avvärja en hotande apokalyps av inhemskt märke. Det är också här det normala Norges och det abnorma Norges vägar korsar varandra: landet pratar och handlar som andra, vilket på ytan gör ett helt normalt intryck. Men i själva verket döljer den transnationella kris-ochnödvändighet-retoriken en nationell abnormitet, som måste hanteras på ett särskilt sätt.

Det finns alltså anledning att närma sig den norska reformprocessen med viss försiktighet. I yttre mening är den skenbart bekant. 200I

43. Det ligger förstås ett mått av sanning i detta, om än med förbehållet att det både i Sverige och i Norge är Socialdemokraterna som realiserat det liberala jämlikhetsbegreppet. Lundberg \& Petersen 2005. 
tillsätts pensionskommissionen vars huvudsyfte får sägas vara att skruva fast den stundande kompromissen i järnhårda och otvetydiga tabeller över åldrande och framtida finansieringsbekymmer. Kommissionens huvudförslag löper också i allmäneuropeisk riktning: att anpassa pensionerna till den ökande medellivslängden, att skapa en ny indexering som beaktar ett genomsnitt av pris- och lönetillväxten samt att införa flexibel pensionsålder på strikt aktuariska villkor (NOU 2004:I). ${ }^{44}$ Så här långt passar den norska processen ganska väl in i de nya välfärdsforskarnas perspektiv. Expansionsfasen ersätts av en inbromsningsfas. Partierna utvecklar gemensamma intressen som partier i förhållande till en förmodat misstänksam väljarkår och tröga institutioner som i kraft av sin betydelse för intressebildningen i samhället genererar sitt eget försvar (Pierson 1994).

Inspirationen från den svenska reformprocessen undgår ingen betraktare. ${ }^{45}$ Det gäller särskilt pensionskommissionens sammansättning, en parlamentarisk arbetsgrupp med understöd av diverse experter som i lugn och ro skulle ges möjlighet att ställa potentiellt bråkiga intressegrupper inför fullbordat faktum. ${ }^{46}$ Rapportens budskap låter sig heller missförstås. Så här ser framtiden ut! Bestrid beräkningarna bakom våra många tabeller och du är diskvalificerad från att delta i diskussionen om detaljerna i systemets närmare utformning!47

Allt verkar så naturligt att det är lätt att förbise det retoriska lappkastet i övergången från 1990-tal till 2000-tal. Under andra halvan av 1990-talet var den förhärskande visdomen att kommande decenniers utgiftsökningar gott och väl kunde finansieras utan alltför kännbara

44. Se även Ervik \& Skogedal Linden 2015, för en analys av motivbilden bakom kommissionens arbete.

45. Se framför allt Marier 20I4, för en detaljerad genomgång baserad på både tidigare forskning, intervjuer och skriftligt material. Marier registrerar I20 referenser till den svenska pensionsreformen i pensionskommissionens slutrapport. Den dyker även upp i remissvar från berörda myndigheter och intresseorganisationer.

46. West Pedersen 2009, som drar slutsatsen att inspirationen från Sverige främst låter sig spåras i initieringsfasen.

47. Ervik och Skogedal Linden framhäver särskilt svårigheterna för eventuella kritiker att presentera en alternativ "policydiskurs" i ljuset av de överlägsna utredningsresurser som stod till pensionskommissionens förfogande. 
skatteökningar. ${ }^{48}$ Folketrygden löpte i upptrampade spår. En viss åtstramning hade skett i början av I990-talet men den allmänna tendensen var att det samlade pensionssystemet successivt blev mer generöst. Mest spektakulär var utbyggnaden av förtidspensionen (AFP) som innebar att merparten av alla anställda i offentlig och privat regi kunde lämna arbetslivet redan vid 62 års ålder utan att deras framtida pension påverkades negativt. Så sent som 1998 - när svenska politiker stod i beredskap att utlösa sitt brutala original - beslutade Stortinget att höja pensionernas lägstanivå med hela 12000 kronor per år (West Pedersen 2009, s. 134).49 Visste man inte vad som komma skulle, skulle man få intrycket av ett godmodigt etablissemang som obekymrat vandrade ut i abnormitetens gränsområden - en fara som för övrigt påpekades av OECD:s ekonomer, som i som årliga genomlysning av norsk ekonomi 20or yrkade på skyndsamma reformer (OECD 200I).

Mot slutet av 1990-talet var alltså befolkningens åldrande fortfarande ett hanterligt problem. För denna tolkning talar om inte annat att de demografiska prognoser som redovisades i utredningar och regeringsrapporter i slutet av 1990-talet knappast skiljer sig från dem som producerades i anslutning till långtidsprogrammet 2002-2005. Åldrandet var i stort detsamma, likaså den förväntade försörjningsbördan. Att sötebrödsdagarna skulle ta slut i mitten av det nya århundradet var också det en etablerad sanning. Det verkligt nya som inträdde i samband med årtusendeskiftet var egentligen det alarmerande tilltalet. För att förstå detta skifte räcker det inte att stirra sig blind på grafiska framställningar över den framtida försörjningsbördan. Bättre i så fall att börja i rädslan för att aktivera de förbannelser, sjukor och paradoxer som slumrade under kontinentalsockeln utanför den norska Atlantkusten. Det var där det verkliga uppvaknandet skedde och det är där

48. Utöver utredningen om fonderingen av folketrygden (NOU I998:I0) som diskuterades ovan kan man peka på den så kallade Velferdsmeldingen (St. meld. nr. 35 [I994I995]) samt långtidsprogrammet I998-200I (St. meld. nr. 4 [1996-I997]).

49. Initiativet kom från Kjell Magne Bondeviks dåvarande borgerliga minoritetsregering bestående av Kristeligt Folkeparti, Venstre och Senterpartiet. Samtidigt som socialdemokraterna bidrog till att realisera liberalernas frihet i jämlikhet bidrog strävade alltså de borgerliga partierna i ett relativt sent skede efter att upprätthålla ett mått av jämlikhet i resultat i de tunga välfärdssystemen. 
man kan se den verkliga skillnaden mellan 1997 och 200I års långtidsprogram, närmare bestämt $\mathrm{i}$ insikten att oljans undanträngda baksida inte främst yttrar sig i en korrumperad elits orientaliska överflöd utan snarare i en välmenande elits troskyldiga värnande av folkets välfärd och jämlikhet. ${ }^{\circ}$

Norge gled i fel riktning. Det är inte heller svårt att dra en rak linje mellan 1996 års utredning om en fonderad folketrygd, som öppnade en avgrund mellan Norge och övriga Europa, via 200I års långtidsprogram, som drog i normaliseringsbromsen, över handlingsregeln, som skärpte budgetdisciplinen och skapade nya finansiella ramar för samhällsutvecklingen, och 200I års pensionskommission, där oljan var ute ur bilden och varje generation måste bära sina egna pensionskostnader. En händelse som i sammanhanget måste ses som en tanke är att pensionskommissionen tillsattes den 30 mars 200I, dagen efter att handlingsregeln hade presenterats för de norska medborgarna.

Man kan läsa pensionskommissionens omfångsrika rapport på många olika sätt, men två argument framträder tydligt i tabell- och textmassorna. Det första argumentet, som rör intäktssidan, är att oljepengarna inte kommer att räcka för att täcka framtidens pensionsförpliktelser. Flera tabeller och figurer är direkt utformade för att skapa en isande känsla hos läsaren. I regeringens mer publiktillvända kortversion av principförslaget som följde på kommissionens rapport har man till och med valt att placera en blodtörstig haj som bakgrund till ett diagram som illustrerar ett växande gap i procent av BNP mellan de samlade

50. Pensionskommissionen berör temat när den diskuterar fondering av folketrygden i ljuset av riskerna för att utlösa naturresursförbannelsen eller dra på sig den holländska sjukan (NOU 2004:I, s. 204-205):

I Norge har vi så langt lykkes i å forvalte petroleumsinntektene på en god måte. Kombinasjonen av store løpende budsjettoverskudd og udekte behov på mange områder gjør likevel at det vil bli svært krevende å føre en økonomisk politikk som ivaretar de langsiktige utfordringene knyttet til aldringen av befolkningen og nedgangen i petroleumsinntektene på en tilfredsstillende måte. Dette kan bli vanskelig hvis en ikke klarer å skape en klarere sammenheng mellom petroleumsinntektene og statens oppbygging av fordringer på den ene siden og de framtidige utgiftene knyttet til eldrebølgen på den annen side. 


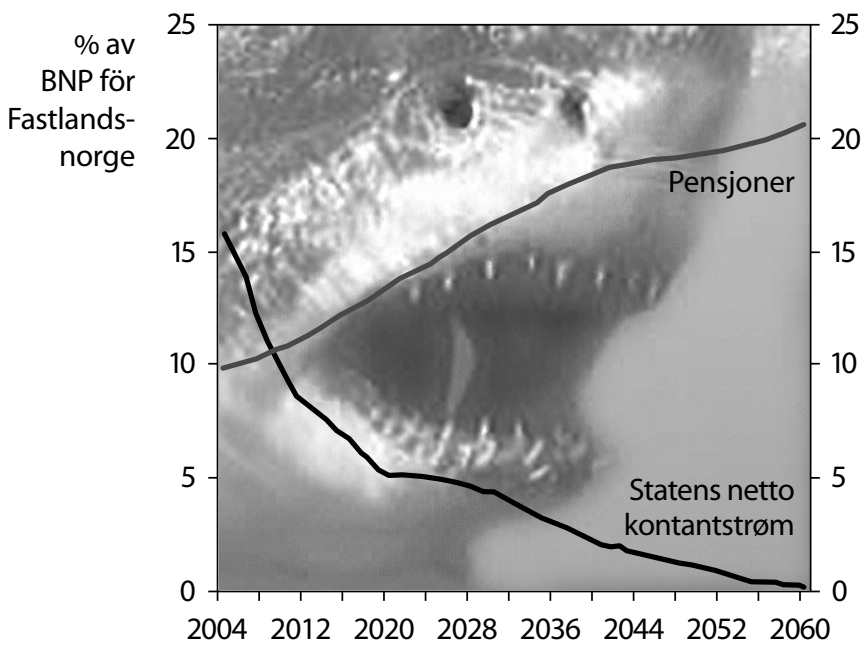

Figur I. Hajkäften. Gapet mellan utgifter för pensioner och inkomster från oljan (Kortversjon av St. meld. nr. I2 [2004-2005], s. 7).

utgifterna i folketrygden och statens nettointäkter från oljeverksamheten (Kortversjon av St. meld. nr. I2 [2004-2005], s. 7). 5I

Budskapet kan knappast missförstås. Inom parentes bör dock påpekas att hajkäftsdiagrammet är delvis vilseledande eftersom det till skillnad från den ursprungliga diagrammet, som återfinns i både pensionskommissionens rapport och regeringens proposition, inte beaktar inkomster från oljefonden efter handlingsregelns införande (NOU 2004:I, s. I5; St. meld. nr. I2 [2004-2005], s. 33). Även i det ursprungliga diagrammet åskådliggörs gapet mellan ökande utgifter och avtagande inkomster, men långt ifrån lika effektfullt. För att bygga vidare på fiskmetaforen (och genom att foga en ny bakgrund till det ursprungliga diagrammet) skulle man kunna säga att den blodtörstiga hajen krymper ihop till en

5 I. Ervik och Skogedal Linden 20I5, har visat att hajgapet dök upp i finansdepartementets snävare policydiskussioner redan 1996-1997 (uppgiften kommer från dåvarande finansministern Jens Stoltenberg) och därefter användes i dess fortsatta både interna och externa argumentering för behovet av reform. På basis av en genomgripande studie av norsk mediedebatt konstaterar de emellertid att metaforens spridning tycks ha varit begränsad. 
ARKIV $\mid$ NR 4

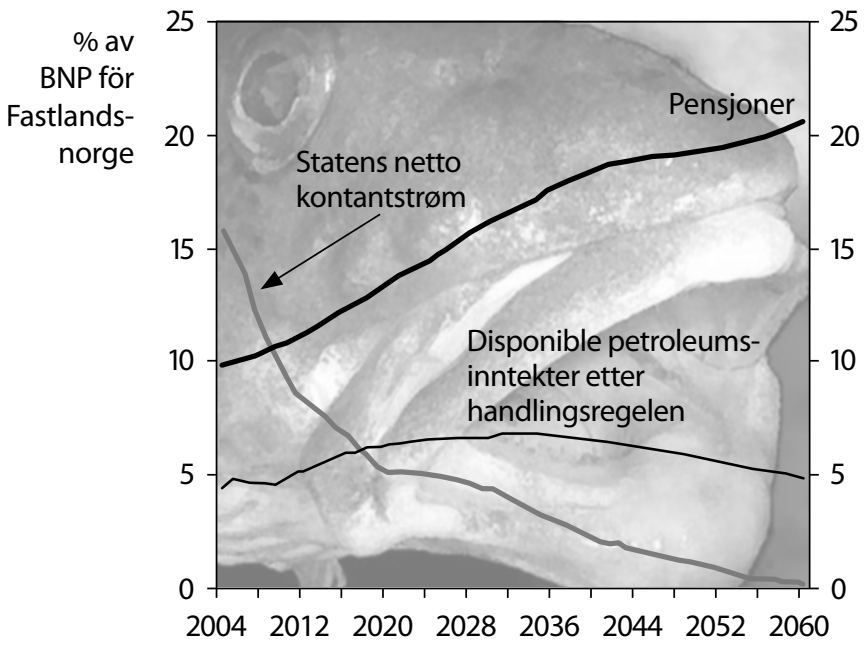

Figur 2. Torskgapet (NOU 2004:I, s. I5; St. meld. nr. I2 [2004-2005], s. 33). Ett stort tack till Oskar Schelin vid Historiska institutionen vid Stockholms universitet, som hjälpte mig med den grafiska utformningen av torskgapsdiagrammet.

gapande torsk med en mjuk underläpp som bromsar in det dramatiska inkomstbortfallet. Därtill bör fogas att idén med en hajkäft är tvivelaktig i sig - som att det skulle vara ett problem att Norge har en betydande intäktskälla som andra länder saknar. ${ }^{52}$

En annan fördel med att byta ut hajen mot en torsk är att handlingsregelns pedagogiska funktion kommer tydligare till uttryck. Oljan reduceras till ett stabilt om än begränsat inflöde som är tillräckligt stort för att ge en känsla av trygghet i det långa loppet men alldeles för litet för att bygga en framtid på (NOU 2004:I, s. 204-205, 2II). Den ställer sig inte i vägen för förändring men gör förändringen mindre olustig - en matsäck att både ta med på resan och avnjuta när man kommit fram. Som statsvetarna Rune Ervik och Tord Skogedal Linden visat var det också i dessa överslätande termer som reformen i slutändan såldes in till den norska befolkningen. Pensionen skulle inte försvinna, eller ens sän-

52. Denna synpunkt framskymtar i LO:s kommentar till pensionskommissionens rapport: att utredarna uteslutande tolkat sitt uppdrag i termer av besparingar och åtstramningar, samt underskattat oljefondens potentiella bidrag, LO 2004. 
kas. I själva verket skulle den bli högre för alla, även om inte alla skulle få lika mycket. Med dåvarande statsministern Jens Stoltenbergs egna ord (i Verldens Gang I7 december 2004, citerat ur Ervik \& Skogedal Linden 2015):

I 2050 vil pensjonistene ha fordoblet kjøpekraft i forhold til i dag. Alle skal få mye mer, men noen skal få litt mindre mer enn andre. Men det kaller ikke jeg kutt.

Mera konkret blir det tydligt hur oljefonden genom handlingsregeln kunde ges ungefär samma funktion som AP-fonderna i den svenska reformprocessen: dels som smörjmedel i övergången från det gamla systemet till det nya, dels som buffert för det nya systemet i tider av obalans. Även detta var i och för sig ett illusionstrick. Oljefonden har lika mycket att göra med AP-fonderna som ett flödande vattenfall med en vattenpöl i Gobiöknen, men givet hur pensionskommissionen byggde upp sin argumentation blev dessa skillnader försumbara. När reformprocessen är fullbordad skall pensionssystemet bära sina egna kostnader; det skall inte vara beroende av en ändlig naturresurs utan finansieras på samma sätt som andra jämförbara pensionssystem, genom mer arbete och ökad produktivitet i den reala ekonomin.

I processen förvandlas oljefonden från en potentiell finansieringskälla till norska löntagares trygghet på ålders höst till en säker trygghetskälla för norsk ekonomi för överskådlig framtid.

Det andra argumentet - som möjliggörs av det första - är att Norge är ett helt vanligt västland. Här är det i stället utgiftssidan som står i centrum - utgifter som nu är befriade från oljan och som uteslutande styrs av hur det rådande systemet fungerar tillsammans med en åldrande demografi. Även detta argument illustrerades med isande tabeller och figurer. Om inga åtgärder vidtogs skulle Norge först isoleras i sitt tillfälliga överflöd för att i nästa skede bestraffas för sin bristande impulskontroll - ett öde landet enligt tabell 3.4 i pensionskommissionens rapport skulle dela med länder som Italien och Spanien. Enligt 
beräkningarna skulle pensionsutgifterna som andel av BNP nästan tredubblas fram till 2050 (NOU 2004:I, s. 52). Den samlade effekten av denna argumentation är tämligen entydig. Norge riskerade att gå från en form för abnormitet till en annan. Det rådande systemets utformning och befolkningens framtida åldrande gjorde att utgifterna måste ned och arbetskraftsdeltagandet upp. ${ }^{33}$

Poängen är inte att pensionskommissionens och regeringens analyser var lögnaktiga, missvisande eller ens felaktiga, endast att den välbekanta argumentationen, de grafiska illustrationer och statistiska uppställningar som vi känner från myriader av liknande rapporter, skyler över att reformprocessen ytterst drevs av en överflödsproblematik snarare än av en kris-, anpassnings- och underskottsproblematik. Finansieringsproblemet såg annorlunda ut och den samtida handlingsrepertoaren var betydligt vidare. Sammantaget innebär detta att reformprocessen blir i det närmaste obegriplig om den okritiskt behandlas inom ramen för den terminologi som utvecklats inom de senaste årens välfärdsforskning. Under den fortsatta reformprocessens gång blir det också tydligt att även lösningarna drar iväg i en självständig riktning. Det yttrar sig framför allt $\mathrm{i}$ att jämlikhets- och jämställdhetsargumenten får ett helt annat utrymme i den norska debatten än i exempelvis den svenska (Marier 2012; West Pedersen 2009).

\section{Brutalt original eller avskräckande exempel?}

Här är inte platsen att redogöra för de skärmytslingar som ledde fram till det slutliga förslag som antogs av Stortinget den 28 maj 2009. Historiens olika turer såväl som systemets konkreta utformning har beskrivits utförligt på annat håll (se framför allt West Pedersen 2009). Här räcker det med att behandla det faktum att den norska reformen i ljuset av den svenska inte tycks gå hela vägen - att den låter sig liknas vid en "halvhjärtad kopia av det brutala originalet”.

53. Se till exempel Kortversjon av Pensjonskommisjonens rapport 2004, s. 4: "Grunnlaget for vår felles velferd er arbeid og de inntekter det gir oss. Arbeidskraften er vår klart viktigste ressurs. Vi må derfor innrette oss slik at den samlede verdien av arbeid kan øke i årene framover." 
Hur skall denna bristande konsekvens förstås? I realiteten öppnade pensionskommissionens rapport två kritiska fronter. Den första var att förslaget inte var radikalt nog. Jämfört med det svenska systemet var försäkringsmässigheten och pensionsförmånernas proportionalitet ofullständig och införandet av en premiepension diskuterades aldrig på allvar - även om Høyre visade visst intresse (NOU 2004:I, s. 238-239). Av allt att döma fanns inga seriösa planer på att skapa ett system som var alltigenom autonomt och självreglerande i förhållande till statsbudgeten (West Pedersen 2009). Tendenser till kritik i denna riktning finns i vissa uttalanden som gjordes när rapporten presenterades, men annars är det främst forskningen som pekat på undfallenhet, bristande konsekvens och flagranta brott mot NDC-modellen (Marier 20I2).

Den begränsade aktiviteten på denna kritiska front behöver inte heller betyda att reformatörerna helst hade anammat det brutala originalet men i tysthet vek ned sig för "de stora förväntningarnas missnöje". Som betonats ovan var det en poäng i sig att reformen ytligt lät sig beskrivas i strukturella termer, att den markerade ett strategiskt avstånd till oljefonden. Därför blev aldrig Hackers tre reformvägar - att driva, skikta eller omvandla - seriösa alternativ. I stället måste det gamla systemet elimineras och det nya häva sig upp på den tredje graden, för att återvända till Halls schema över institutionell förändring. Men även genomgripande reformer kan ta sig olika uttryck och det finns egentligen inga belägg för att siktet inledningsvis var inställt på den rättvisa som det svenska systemet graviterar mot (där proceduren är viktigare än utfallet). I jämförelse med den svenska pensionsarbetsgruppen, vars rapport är impregnerad av stränga rättviseargument, är de norska reformatörerna betydligt mer öppna för nya systemets jämlikhets- och fördelningsaspekter. ${ }^{54}$

Den andra kritiska fronten var följaktligen att förslaget var alltför radikalt och att ambitionen att knyta pensionerna hårdare till livsinkomsten stod i konflikt med traditionella fördelningspolitiska mål - kort sagt att systemet i pensionskommissionens ursprungliga förslag blev svårt att försvara ur både jämlikhets- och jämställdhetssynpunkt. På denna flank

54. Redan i pensionskommissionens rapport från 2004 finns gott om exempel på detta. Bland annat avfärdas den svenska premiepensionslösningen med hänvisning till riskerna för ett alltför ojämlikt utfall. 
var aktiviteten desto flitigare (Ervik \& Skogedal Linden 20I5). En rimlig förklaring till detta är att den norska reformprocessen var betydligt mer utdragen än den svenska, där intressegrupperna exkluderades och de principiella riktlinjerna drogs upp och beslutades mellan två val (West Pedersen 2009; Marier 20I2; Ervik \& Skogedal Linden 20I5). I Sverige var det även politikerna som ansvarade för själva implementeringen (Lundberg 2003). Det norska upplägget var mer traditionellt (trots de ytliga likheterna med Sverige). Pensionskommissionens förslag presenterades i god tid före valet 2005 och blev föremål för intensiva diskussioner, där även partiledarna deltog. Även implementeringen genomfördes i traditionella former av ansvariga myndigheter (Marier 20I4). Medan man i Sverige skapade en helt ny reformväg vid sidan av demokratins infrastrukturer med hänsyn till det allvarsamma ekonomiska läget och systemets interna rationalitetskrav, kunde de norska reformatörerna i högre grad kosta på sig att maximera reformens demokratiska legitimitet.

Till skillnad från i Sverige fick både Arbeiderpartiets interna debatt och intresseorganisationernas, särskilt LO:s, kritik stort genomslag. Till och med väljarna fick säga sitt. I och med att Arbeiderpartiets allians med Sosialistisk Venstreparti gick segrande ur valstriden 2005 ökade lyhördheten för kritiken mot förslagets avigsidor ytterligare. Därmed drev systemet i social riktning (Marier 20I4). Garantipensionen höjdes till nivåer som underminerade NDC-modellen. Indexeringen fick en ur pensionärskollektivets synvinkel mer gynnsam utformning. Möjligheterna till förtidspension inom AFP-ordningen blev kvar, för privatanställda främst till namnet, för offentliganställda också i praktiken. Liknande förslag framfördes i Sverige, särskilt i Socialdemokraternas interna debatt, men lyckades aldrig bryta upp den policykartell som partiledningarna skapat kring frågan (Lundberg 2003). Därmed inte sagt att policyprocessens jämförelsevis öppna struktur rymmer hela sanningen. En naturlig motfråga är hur man med tanke på de allvarliga problem som pensionskommissionen drog fram i ljuset kunde kosta på sig att frångå de nya välfärdsforskarnas handlingsrekommendationer.

Så vari bestod egentligen den norska reformens etos? I Sverige var reformbehovet akut. Underskotten växte, arbetslösheten skenade, förtroendet för politikerna var bottenlågt. När krisen under första halvan 
av I990-talet var som allra djupast strömmade kapitalet ut ur landet i en hastighet som föranledde Riksbanken att driva upp räntan till 500 procent. Hela välfärdsstaten stod på spel och med den hela den nationella identiteten. I Norge gick ekonomin för högvarv. Pengarna samlades på hög. Därför blir det också märkligt att värdera den norska reformen i ljuset av den svenska. Hotbilden var helt annorlunda, förlagd till en diffus framtid och intimt sammanflätad med de särskilda svårigheter som är förenade med att förvalta en ändlig naturresurs. Därmed var även målbilden en helt annan och fullt naturligt också resultatet. Det är mot denna bakgrund som den norska reformen skall värderas.

Visst fanns beröringspunkter med den svenska reformen, framför allt i sättet på vilket den norska processen inledningsvis riggades till förmån för normaliseringslinjen och i ambitionen att skapa ett helt nytt system på ruinerna av det gamla. I övrigt torde den svenska reformen både till form och till innehåll snarast ha tjänat som ett avskräckande exempel.

\section{Svårt, mycket svårt}

$\mathrm{Ja}$, det var svårt, mycket svårt, men svårigheten bestod inte främst $\mathrm{i}$ att driva igenom en genomgripande pensionsreform utan $\mathrm{i}$ att de goda omständigheterna till trots tvinga in Norge $\mathrm{i}$ en permanent omloppsbana kring det postindustriella problemkomplexets allmäneuropeiska kärna. Man var inte som andra men kunde i alla fall prata och göra som andra. Det var svårt, mycket svårt och därför hamnade reformen i det internationella policyuniversumets yttre gräns. Utan tvekan har den en viss familjelikhet med vissa andra reformer, också den svenska, men den löser inte självklart samma problem som dessa reformer.

Mest påtagligt är att den viker undan för de radikala ställningstaganden som är det svenska systemets och i någon mån hela NDC-modellens särmärke. Det gäller premiepensionen, som i Norge (på goda grunder) avfördes i ett tidigt skede. Det gäller förtidspensioneringen, som avskaffades helt i Sverige men som blev kvar för offentliganställda i Norge. Det gäller ambitionen att skapa ett autonomt system som är både externt följsamt och internt självreglerande - en svensk kungstanke som de norska reformatörerna aldrig nappade på. Det gäller framför allt garanti- 
pensionens utformning och generositet, som i mångt och mycket neutraliserar de kritiska frågor rörande nyfattigdom, ojämlikhet och klassoch genusorättvisor som fortsätter att hemsöka den svenska debatten.

Sammantaget innebär detta att den norska reformen är tämligen svårklassificerad. Man kan säga att den uppträder under NDC-förklädnad men ännu inte avslöjat sin rätta identitet. Ändå menar jag att man hamnar fel om man avfärdar den som ett yrvaket yttryck för slapphet och hållningslöshet inför demografins och globaliseringens dubbla tryck. Det var svårt, mycket svårt eftersom man laborerade med två apokalyptiska framtidsscenarier - åldrande och olja - och den mest uppenbara lösningen, att desarmera det förra med det senare, enligt en samstämmig expertis skulle resultera i en fullständig katastrof. Först när den norska pensionsreformen betraktas ur detta inhemska perspektiv blir den begriplig, kanske också försvarlig. Om inte annat får man en känsla för anspänningen. Det var svårt, mycket svårt, därför måste man också uppmärksamma hur partiernas företrädare i processen tvingades träda in i en delvis ny roll i förhållande till sina väljare.

Välfärdspolitik har alltid varit en fråga om mobilisering och integration - om att antingen flytta fram sina positioner, kräva mer och bättre åt dem som redan har, eller organisera grupper som tidigare varit utestängda från den politiska processen. Det är så pensionssystem byggts upp, förbättrats och genom historien successivt omfattat allt fler människor. I detta har politikerna uppträtt som företrädare för antingen sociala intressen eller moralisk aktivism. Det är också så de har uppfattats i forskningen. Å ena sidan har de bevisligen funnits där; det är genom deras agerande som sociala intressen och social kritik omsatts i praktisk handling och konkreta institutioner. $\AA$ andra sidan har deras personer varit att likna vid tomma burkar eller utbytbara enheter. Personlighetens genomslag är blygsamt för att inte säga direkt obefintligt i den samhällsvetenskapliga välfärdsforskningen.

Så vilka svårigheter ställdes politikerna inför? I Sverige var svårigheterna av teknokratisk och maktpolitisk karaktär, vilket resulterade i en strategisk arsenal som blev svår att hantera inom ramen för vedertagna demokratiska begrepp. Liknande tendenser finns i den norska processen, men de är mer kopplade till oljan än till pensionerna. Medan hand- 
lingsregeln förhandlades och förankrades i det politiska etablissemanget under största hemlighet och med hänsyn till de kollektiva handlingsproblem som är förenade med att hantera en ändlig naturresurs, var pensionsreformen en jämförelsevis öppen process som drog nytta av de vägar till folklig legitimitet som de demokratiska institutionerna erbjuder. I stället finns det alltså skäl att överväga om inte oljeproblematiken - den ofrivilliga valfriheten - har skapat en särskild norsk politikertyp, mer förankrad i det amerikanska senatorsämbetet än de renodlade intresse- och idépolitiker som förknippas med den parlamentariska demokratin.

Kanske man kan uttrycka det som att i takt med att fler och fler politikområden skuggas av en framtid där oljan förväntas ta slut, antar politikerna (och därmed politiken) en ny karaktär. De förlorar tålamodet med samtidens trivialiteter, börjar bete sig annorlunda. Deras blickar riktas mot färran. De griper inte in utan försöker ständigt föregripa. Inget dagsaktuellt problem förmår riktigt mäta sig med de bekymmer som väntar när domedagen infaller och hela samhällsstrukturen måste anpassas till nya omständigheter.

Den amerikanske statsvetaren Andrew Sabl tilldelar en idealtypisk senator två uppgifter i en demokrati: att överlägga och att jämka ihop, såväl intressen och ideologier som olika förslag. Senatorn representerar sina väljare men i ämbetets natur ligger att aldrig ge efter för populistiska stämningar (Sabl 2002, s. I2). Allt måste betraktas inom ramen för helheter och generationsöverskridande förlopp. Som Sabl uttrycker det: ”De eftersträvar politiska lösningar som valmanskåren kanske inte känner starkt för i nuet eller ens förstår, men kommer att godkänna med tiden [...] som varande i linje med deras långsiktiga mål” (Sabl 2002, s. I2). Hit kan man foga att det var svårt, mycket svårt eftersom norska politiker har kortare mandatperioder än amerikanska senatorer. I detta avseende innebar pensionsreformen en risk som de hanterade genom att dels isolera oljan från pensionerna, dels skruva fast behovet av reform i en analys som väljarna inte utan vidare kunde rucka på. Att systemet under den fortsatta reformprocessen - när kritikerna fick sätta tänderna i det - rörde sig i social riktning behöver inte heller ses som något negativt eller som ett bevis på norska politikers undfallenhet. 
För det första finns ingen anledning att tvivla på norska väljares kunskap om de ekonomiska sambanden. 55 I likhet med sina politiker lever de med oljan. De vet att tiderna är goda, likaväl som de vet att oljeplattformarna inte kommer stå där för alltid. Att inte väga in denna kunskap i den slutliga reformen hade inte bara varit kontraproduktivt - givet att reformen och dess konsekvenser ofrånkomligen kommer att betraktas $\mathrm{i}$ det skarpa skenet av ett faktiskt överflöd. Det hade också varit att driva normaliseringslinjen för långt. Det är skillnad mellan att utforma system som skall samexistera med permanenta underskott och system som skall samexistera med permanenta överskott. Det är också mot denna bakgrund som man måste förstå oviljan att isolera pensionerna från statsbudgeten - att norska politiker någon gång emellanåt har goda skäl att stämma in i sirenernas skönsång. ${ }^{56}$

För det andra finns ingen anledning att trivialisera respekten för väljarna. Som betonats speglar ett pensionssystem många saker. I en demokrati vore det förstås märkligt om det inte också speglade väljarnas önskemål och verklighetsbilder.

För det tredje, vilket följer av det ovanstående, kommer väljarnas önskemål ändå till uttryck i det långa loppet. Inte ens den mest cementerade kartell, den mest svårforcerade vakuumförpackning, överlever väljare som visar sitt missnöje i upprepade val. Det gäller särskilt i Norge med sin ofrivilliga valfrihet. ${ }^{57}$

55. Resonemanget nedan är inspirerat av Sabl 20I2, s. I56-I59.

56. Redan Tempoutvalget konstaterade att en fond inte kan "erstatte de politiske myndigheters egen vilje til å legge fremtidsrettede hensyn til grunn for sin politikk." NOU I983:27, s. IO2.

57. Redan i dag har man noterat ett flertal problem med handlingsregeln. Ett första är att den i goda tider ger utrymme för en alltför expansiv finanspolitik - ett problem man löst genom att emellanåt låta användningen av oljepengarna ligga under de stipulerade 4 procenten. Ett andra problem är att oljefonden på sikt riskerar att bli för stor för pensionssystemet. Annorlunda uttryckt: om fonden i sin helhet öronmärks för pensionerna är risken att pensionerna blir för stora. Att pensionärerna får dela på de risker som är förenade med oljefonden är en sak, men enligt vissa bedömare är det inte försvarligt att låta dem dra nytta av alla fördelar. En annan kritik som framförts är att gränsen 4 procent av realavkastningen är alltför optimistisk på lång sikt (fonden har inte uppnått sin slutliga storlek) och att den redan nu borde sänkas till 3 procent. 
För det fjärde handlar det om att befästa en ömsesidig sympati för demokratins villkor. Här kan den svenska reformprocessen, där politikerna upprepade gånger ignorerade sina väljares åsikter, ha tjänat som ett avskräckande exempel. I förlängningen väntar ett sluttande plan på vilket folkvalda förväntar sig att väljarna skall tillbe dem som ett slags gudalika varelser med makt att tänka i deras ställe.

Det var svårt, mycket svårt eftersom all form av framtidsinriktad lagstiftning innebär en avancerad balansakt mellan att offra framtiden för samtiden och att offra samtiden för framtiden. Någon varaktig lösning på detta dilemma finns inte. Alla framtidsscenarier tar spjärn mot ett gungfly av uppskattningar och lösa antaganden. Till och med demografiska prognoser vilar på ett betydande mått av osäkerhet, särskilt om de sträcker sig femtio eller hundra år in i framtiden, med följd att de i första hand bör betraktas i den samtid där de produceras (Lindh \& Lundberg 2008). Det innebär också att alla bindningsstrategier och automatiska lösningar förr eller senare kommer att smulas sönder av en okänd framtida väljarkårs okända värderingar. Ställda inför dessa tidskonsistensproblem valde de norska politikerna en ödmjukare och kanske även rimligare hållning än de svenska. De reducerade oljefonden till en godhjärtad och lagom generös onkel och satte delar av pensionssystemet på autopilot, men undvek att skapa illusionen av ett isolerat och helautomatiskt system som skall överleva till nästa istid.

Det var svårt, mycket svårt, men möjligen gjorde de norska politikerna det bästa av saken, eller till och med det de hade föresatt sig. De krånglade sig ur oljeproblematiken och dess ofrivilliga valfrihet, de lyckades vinna förståelse för normaliseringslinjen utan att för den skull skapa ett pensionssystem som stred mot väljarnas förnuft och önskan att bevara ett mått av kontinuitet med det förflutna. Hegels intellektuella kungadöme öppnade sina portar. Än viktigare: de lyckades driva igenom reformen utan att kringgå demokratins gängse infrastrukturer. Att resultatet saknar internationell lyskraft har i sammanhanget mindre betydelse eftersom Norge i allt väsentligt kvarstår som ett land utan jämförelsepunkter.

En svår fråga lämnades dock obesvarad: Vad är det för nytta med pengar om de inte får användas? Det officiella svaret tycks vara trygghet 
i det långa loppet, vilket i sin tur väcker nya frågor: Vilket slags trygghet handlar det om, vems trygghet gäller det när pengarna inte öronmärks för specifika ändamål? Och inte minst: Trygghet mot vad? På den sista frågan, som nästan ingen törs ställa, finns än så länge bara inofficiella svar - svar som längs vindlande vägar för ned i en dunkel sagovärld befolkad av slumrande men lättväckta andeväsen vars förbannelser och mäktiga magi skapar beröringsångest inför varje oförtjänt förmögenhet.

\section{Referenser}

Andersen, J. G. \& Bjørklund, T. (2000) "Radical right-wing populism in Scandinavia. From tax revolt to neo-liberalism and xenophobia". I: P. Hainsworth (red.), Politics of the extreme right. From the margins to the mainstream. Continuum International, New York.

Andersen, J. G. \& Bjørklund, T. (2008) "Scandinavia and the far right". I: P. Davies \& P. Jackson (red.), The far right in Europe. An encyclopedia. Greenwood World Publishing, Oxford.

Anderson, K. M. \& Immergut, E. M. (2007) "Sweden. After social democratic hegemony". I: E. M. Immergut, K. M. Anderson \& I. Schulze (red.), The handbook of West European pension politics. Oxford University Press, Oxford.

Andersson, J. (2006) Between growth and security. Swedish social democracy from a strong society to a third way. Manchester University Press, Manchester.

Angell, S. I. (2012) Two variants of decentralised health care: Norway and Sweden in comparison. Working paper 4, Stein Rokkan senter for flerfaglige samfunnsstudier, Bergen. URL: http://cms.uni.no/media/manual_upload/305_wp_04_200I2_angell.pdf (22 september 2015)

Auty, R. (1993) Sustaining development in mineral economies. The resource curse thesis. Routledge: London.

Belfrage, C. (2007) "Den villige, den tveksamme, den hopplöse. En svensk massinvesteringskultur". I: U. Lundberg (red.), Mellan folkbildning och fondrådgivning. Nya perspektiv på pensionssystemet. Institutet för framtidsstudier, Stockholm.

Bjørnson, Ø. \& Haavet, Е. (1994) Langsomt blev landet et velferdssamfunn. Trygdens historia I884-1994. Gyldendal, Oslo.

Bonoli, G. (2000) The politics of pension reform. Institutions and policy change in Western Europe. Cambridge University Press, Cambridge.

Bonoli, G., George, V. \& Taylor-Gooby, P. (2000) European welfare state futures. Towards a theory of retrenchment. Polity Press, Cambridge.

Brooks, S. M. \& Weaver, R. K. (2006) "Lashed to the mast? The politics of NDC pension reform". I: R. Holzmann \& E. Palmer (red.), Pension reform. Issues and prospects for non-financial defined contribution (NDC) schemes. Världsbanken, Washington DC. 
Campbell, J. L. (2004) Institutional change and globalization. Princeton University Press, Princeton.

Caminada, K., Goudswaard, K. P. \& van Vliet, O. (20I0) "Patterns of welfare state indicators in the EU. Is there convergence?" Journal of Common Market Studies, vol. 48, nr 3.

DoI: http://dx.doi.org/IO.IIII/j.I468-5965.20I0.02063.x

Cappelen, Å. (2002) "Petroleumsfond og handlingsregel for finanspolitikken”. I: N. Bjerkedal m.fl. (red.), Finansråd $i$ utfordrende tider. Finansdepartementet, Oslo.

Dahlberg, J. (20I4) "Nonsens om pensionerna”. Svenska Dagbladet, 28 december. URL: http://www.svd.se/nonsens-om-pensionerna (22 september 20I5)

Ekenberg, T. (20I2) "Auktoritet och den fria viljan hos Anselm, Kant och Wolff". Tidskrift för politisk filosofi, vol. I6, nr 2.

URL: http://www.politiskfilosofi.se/fulltext/20I2-2/pdf/20I2-2_006-oI6_

ekenberg.pdf (22 september 2015)

Elster, J. (1979) Ulysses and the sirens. Cambridge University Press, Cambridge.

Elster, J. (1985) "Rationality, morality, and collective action". Ethics, vol. 96, nr I. DOI: http://dx.doi.org/IO.IO86/292725

Elster, J. (2000) Ulysses unbound. Studies in rationality, precommitment, and constraints. Cambridge University Press, Cambridge.

Ervik, R. \& Skogedal Linden, T. (2015) "The shark jaw and the elevator: arguing the case for the necessity, harmlessness and fairness of the Norwegian pension reform". Scandinavian Political Studies, nätpublicering 15 mars. DoI: http://dx.doi.org/IO.IIII/I467-9477.12049

Esping-Andersen, G. (I999) Social foundations of postindustrial economies. Oxford University Press, New York.

Esping-Andersen, G. (1990) The three worlds of welfare capitalism. Polity Press, Cambridge. Flood, L. (2007) "Can we afford the future? An evaluation of the new Swedish pension system". I: A. Gupta \& A. Harding (red.), Modelling our future. Population ageing, social security and taxation. Elsevier, Amsterdam.

Forslund, D. (2007) "Högsta vinsten”. I: U. Lundberg (red.), Mellan folkbildning och fondrådgivning. Nya perspektiv på pensionssystemet. Institutet för framtidsstudier, Stockholm.

Forslund, D. (2008) Hit med pengarna! Sparandets genealogi och den finansiella övertalningens vetandekonst. Carlsson, Stockholm.

Fredriksen, D. \& Stølen, N. M. (2011) Norwegian pension reform. Defined benefit versus defined contribution. Discussion paper 669, Statistisk sentralbyrå, Oslo.

URL: http://www.ssb.no/a/publikasjoner/pdf/DP/dp669.pdf (22 september 2015)

Green-Pedersen, C. (2002) The politics of justification. Party competition and welfare state retrenchment in Denmark and the Netherlands from 1982 to 1998. Amsterdam University Press, Amsterdam.

Gylfason, T. (200I) "Natural resources, education, and economic development". European Economic Review, vol. 45, nr 4-6.

DoI: http://dx.doi.org/IO.IOI6/SooI4-292I(OI)ooI27-I 
Gylfason, T. (20II) Natural Resource Endowment. A Mixed Blessing? Working Paper nr 3353, CESifo, München.

URL: https://www.cesifo-group.de/ifoHome/publications/working-papers/

CESifoWP/CESifoWPdetails?wp_id=I5III688 (22 september 20I5)

Hacker, J. (2004) "Policy drift: the hidden politics of US welfare state retrenchment". I:

W. Streeck, \& K. Thelen (red.), Beyond continuity. Oxford University Press, Oxford.

Hagen, T. P. \& Kaarbøe, O. M. (2006) "The Norwegian hospital reform of 2002. Central government takes over ownership of public hospitals". Health Policy, vol. 76, nr 3. DOI: http://dx.doi.org/Io.IoI6/j.healthpol.2005.06.0I4

Hall, P. (I993) "Policy paradigms, social learning, and the state". Comparative Politics, vol. $25, \mathrm{nr} 3$.

DOI: http://dx.doi.org/Io.2307/422246

Halvorsen, K. \& Stjernø, S. (2008) Work, oil and welfare. The welfare state in Norway. Universitetsforlaget, Oslo.

Hatland, A. (red.) (20II) Veivalg i velferdspolitikken. Fagboksforlaget, Oslo.

Hegel, G. W. F. (2005 [I82I]) Philosophy of right. Dover, Mineola.

Hinrichs, K. \& Kangas, O. (2003) "When is a change big enough to be a system shift? Small system-shifting changes in German and Finnish pension policies". Social Policy \& Administration, vol. 37 , nr 6 .

DoI: http://dx.doi.org/IO.IIII/I467-9515.00359

Holden, S. (20II) Avoiding the resource curse. The case of Norway. Paper framlagt vid konferensen Oil Revenue Management i Ghana, 26-27 april $201 \mathrm{I}$.

URL: http://folk.uio.no/sholden/wp/resource-curse-norway-I3.pdf (22 september 2015)

Hort, Sven E. O. (20I4) Social policy, welfare state, and civil society in Sweden. Volume II: The lost world of social democracy. Arkiv förlag, Lund.

Hylland, A. (2005) "Statens reservefond 1904-1925. Et forsøk på å binde politisk handlefrihet?" Penger og Kreditt, nr 3.

URL: http://www.norges-bank.no/Upload/import/publikasjoner/penger_og_ kreditt/2005-03/hylland.pdf (22 september 2015)

Häusermann, S. (2010) The politics of welfare state reform in continental Europe. Modernization in hard times. Cambridge University Press, New York.

Kangas, O. (2007) "Finland: labor markets against politics". I: E. M. Immergut, K. M. Anderson \& I. Schulze (red.), The handbook of West European pension politics. Oxford University Press, Oxford.

Kant, I. (1997 [I785]) Grundläggning av sedernas metafysik. Daidalos, Göteborg.

Karl, T. L. (1997) The paradox of plenty. Oil booms and petro-states. University of California Press, Berkeley.

Kersbergen, K. van (2000) "The declining resistance of welfare states to change". I: S. Kuhnle (red.), The survival of the European welfare state. Routledge, London.

Korpi, W. (1983) The democratic class struggle. Routledge \& Kegan Paul, London.

Kortversjon av Pensjonskommisjonens rapport (2004) Modernisert folketrygd-barekraftig pensjon for framtida (NOU 2004:I). Finansdepartementet, Oslo. 
Kortversjon av St. meld. (Stortingsmelding) nr. I2 (2004-2005) Pensjonsreform - trygghet for pensjonene. Finansdepartementet, Oslo 2004.

Kuhnle, S. (2000) "The Scandinavian welfare state in the I99os. Challenged but viable". West European Politics, vol. 23, nr 2. DOI: http://dx.doi.org/Io.IO80/oI402380008425373

Kydland, F. E. \& Prescott, E. C. (I977) "Rules rather than discretion. The inconsistency of optimal plans". Journal of Political Economy, vol. 85, nr 3.

URL: http://www.jstor.org/stable/I830I93 (22 september 2015)

Lindh, T. \& Lundberg, U. (2008) "Predicaments in the futures of ageing democracies". Futures, vol. 40, nr 3 . DOI: http://dx.doi.org/IO.IoI6/j.futures.2007.08.020

Lindvall, J. (2006) Ett land som alla andra. Från full sysselsättning till massarbetslöshet. Atlas, Stockholm.

LO (Landsorganisasjonen i Norge) (2004) Høringsuttalelse I4 juni, NOU 2004:I. Modernisert folketrygd - barekraftig pensjon for framtida.

Lov om Statens Petroleumsfond, 22 juni 1990.

Lundberg, U. (2003) Juvelen i kronan. Socialdemokraterna och den allmänna pensionen. Hjalmarson \& Högberg, Stockholm.

Lundberg, U. (2009) "The democratic deficit of pension reform. The case of Sweden". I: K. Petersen \& J. H. Petersen (red.), The politics of age. Basic pension systems in a comparative and historical perspective. Peter Lang, Frankfurt am Main.

Lundberg, U. (20I2) "Pensionssystemet - en rättvis fördelning över livsloppet?" I: L. Andersson \& P. Öberg (red.), Jämlik ålderdom? I samtiden och framtiden. Liber, Stockholm.

Lundberg, U., Kangas, O. \& Ploug, N. (20I0) "Three routes to pension reform. Politics and institutions in reforming pensions in Denmark, Finland and Sweden". Social Policy \& Administration, vol. 44, nr 3.

DOI: http://dx.doi.org/I0.IIII/j.I467-9515.2010.00713.x

Lundberg, U. \& Petersen, K. (2005) "Socialdemokratiet og velfærdsstaten i et nyt politisk landskab? Et essay om moderne velfærspolitik". Arbejderhistorie. Tidsskrift for historie, kultur og politik, nr 4.

URL: http://sfah.dk/upload_dir/pics/Tidsskrift/Aargang-2005/nr4/AHo5-4-U_

Lundberg-K_Petersen.pdf (22 september 2015)

Lynch, J. (2006) Age in the welfare state. The origins of social spending. Cambridge University Press, Cambridge.

Lægreid, P., Opedal, S. \& Stigen, I. M. (2005) ”The Norwegian hospital reform. Balancing political control and enterprise autonomy". Journal of Health Politics, Policy and Law, vol. 30 , nr 6 .

DoI: http://dx.doi.org/IO.I215/03616878-30-6-1027

Machiavelli, N. (200I [I53I]) Discorsi sopra la prima deca di Tito Livio. Vol. I. Salerno Editrice, Rom.

Madison, J., Hamilton, A. \& Jay, J. (1987 [1788]) The federalist papers. Penguin Classics, London. 
Mahoney, J. \& Thelen, K. (20I0) "A theory of gradual institutional change". I: J. Mahoney \& K. Thelen (red.), Explaining institutional change. Ambiguity, agency, and power. Cambridge University Press, Cambridge.

Marier, P. (2008) "Empowering epistemic communities. Specialised politicians, policy experts and policy reform". West European Politics, vol. 31, nr 3. DOI: http://dx.doi.org/Io.Io8o/oI402380801939800

Marier, P. (20I4) "A Swedish pension reform in Norway? A critical analysis of policy diffusion and policy transfer". Les cahiers du CREGES, $\mathrm{nr} 2$.

Mehlum, H., Moene, K. \& Torvik, R. (2006) "Institutions and the resource curse". Economic Journal, vol. II6, nr 508.

DOI: http://dx.doi.org/IO.IIII/j.I468-0297.2006.0I045.x

Montanari, I., Nelson, K. \& Palme, J. (2008) "Towards a European social model?” European Societies, vol. I0, $\mathrm{nr} 5$. DOI: http://dx.doi.org/IO.IO80/I366880080I9I2543

Myles, J. \& Pierson, P. (200I) "The comparative political economy of pension reform". I: P. Pierson (red.), The new politics of the welfare state. Oxford University Press, Oxford.

Norges Bank (2015) Statens Pensjonsfond utland: Årsrapport 20I4. Norges Bank Investment Management, Oslo.

URL: http://www.nbim.no/apenhet/rapporter/2OI4-new/arsrapport-20I4/ (22 september 2015)

NOU 1983:27. Petroleumsvirksomhetens framtid. Det framtidige omfanget av petroleumsvirksombeten på norsk sokkel.

NOU 1988:21. Norsk økonomi i forandring. Perspektiver for nasjonalformue og økonomisk politikk i I9go-årene.

NOU i998:Io. Fondering av folketrygden?

NOU 2004:I. Modernisert folketrygd - Berekraftig pensjon for framtida.

Nyqvist, A. (2008) Opening the orange envelope. Reform and responsibility in the remaking of the Swedish national pension system. Stockholms universitet, Stockholm.

OECD (200I) Economic Survey. Norway. OECD, Paris.

Olsen, Ø. (1995) Statens petroleumsfond. Et styrningsverktøy for finanspolitikken. Föredrag på Sosialøkonomisk Forenings konjunkturseminarium 7 september 1995 .

URL: https://www.regjeringen.no/nb/tema/okonomi-og-budsjett/statenspensjonsfond/internt-bruk/statens-petroleumsfond---et-styringsverk/id429520/ (22 september 2015)

Olson, M. (1965) The logic of collective action. Public goods and the theory of groups. Harvard University Press, Cambridge.

Palme, M., Gruber, J. \& Wise, D. A. (2010) Social security programs and retirement around the world. The relationship to youth employment. University of Chicago Press, Chicago.

Pensionssystemet, blev det som tänkt? Vad behöver göras? (20II) PRO, Stockholm.

Petersson, J. (2009) "Lottovinsten gör dig inte lyckligare”. Svenska Dagbladet, 24 april. URL: http://www.svd.se/lottovinsten-gor-dig-inte-lyckligare (22 september 2015)

Pierson, P. (1994) Dismantling the welfare state? Reagan, Thatcher, and the politics of retrenchment. Cambridge University Press, Cambridge. 
Pierson, P. (1996) "The new politics of the welfare state". World Politics, vol. 48, nr 2. URL: http://www.jstor.org/stable/25053959 (22 september 2015)

Pierson, P. (200I) "Coping with permanent austerity. Welfare restructuring in affluent democracies". I: P. Pierson (red.), The new politics of the welfare state. Oxford University Press, Oxford.

Pierson, P. (red.) (200I) The new politics of the welfare state. Oxford University Press, Oxford.

Pollitt, C. \& Bouckaert, G. (2004) Public management reform. A comparative analysis. Oxford University Press, Oxford.

Ramey, G. \& Ramey, V. A. (I995) "Cross-country evidence on the link between volatility and growth". The American Economic Review, vol. 85, $\mathrm{nr} 5$.

URL: http://www.jstor.org/stable/2950979 (22 september 2015)

Rieger, E. \& Liebfried, S. (2003) Limits to globalization. Polity, Cambridge.

Rose, N. (1999) Powers of freedom. Reframing political thought. Cambridge University Press, Cambridge.

Ross, M. L. (2012) The oil curse. How petroleum wealth shapes the development of nations. Princeton University Press, Princeton.

Ruin, O. (1986) I välfärdsstatens tjänst. Tage Erlander 1946-I969, Tiden, Stockholm.

Ryner, M. J. (2002) Capitalist restructuring, globalisation and the third way. Lessons from the Swedish model. Routledge, London.

Røed Larsen, E. (200I) "The Norwegian economy 1900-2000. From rags to riches. A brief history of economic policymaking in Norway". Economic Survey, nr 4. URL: https://www.ssb.no/a/histstat/es/es_200I_04.pdf (22 september 20I5)

Røed Larsen, E. (2002) Escaping the natural resource curse and the Dutch disease? Norway's catching up with and forging ahead of its neighbors. Paper från Econometrics Laboratory (EML) vid University of California at Berkeley.

URL: http://eml.berkeley.edu/ -webfac/cbrown/e25I_fo3/larsen.pdf (22 september 2015)

Røed Larsen, E. (2006) "Escaping the resource curse and the Dutch disease? When and why Norway caught up with and forged ahead of its neighbors". American Journal of Economics and Sociology, vol. 65, nr 3. DOI: http://dx.doi.org/IO.IIII/j.I536-7I50.2006.00476.x

Sabl, A. (2002) Ruling passions. Political offices and democratic ethics. Princeton University Press, Princeton.

Sachs, J. D. \& Warner, A. M. (200I) "The curse of natural resources". European Economic Review, vol. 45, nr 4-6. DOI: http://dx.doi.org/Io.IoI6/SooI4-292I(oI)ooI25-8

Salminen, K. (1993) Pension schemes in the making. A comparative study of the Scandinavian countries. Pensionsskyddscentralen, Helsingfors.

Sandø, T. (2013) "Historien om handlingsregelen". Aftenposten, 8 november.

Sartre, J.-P. (1976 [1943]) L'être et le néant. Essai d'ontologie phénoménologique. Gallimard, Paris.

Schelling, T. C. (1978) "Egonomics, or the art of self-management". The American Economic Review, vol. 68, $\mathrm{nr} 2$.

URL: http://www.jstor.org/stable/I8I6707 (22 september 20I5) 
Schmitt, C. \& Starke, P. (20II) "Explaining convergence of OECD welfare states. A conditional approach". Journal of European Social Policy, vol. 2I, nr 2. DOI: http://dx.doi.org/IO.II77/0958928710395049

Seip, A.-L. (1994) Veiene til velferdsstaten. Norsk sosialpolitikk 1920-1975. Gyldendal, Oslo. Sejersted, F. (2005) Socialdemokratins tidsailder. Sverige och Norge under Igoo-talet. Nya Doxa, Nora.

Smith, A. (I909-I9II [I776]) En undersökning av folkens välstånd, dess natur och orsaker. 2 vol., Gleerup, Lund.

St. meld. (Stortingsmelding) nr. 35 (1994-1995) Velferdsmeldingen.

St. meld. nr. 4 (1996-1997) Langtidsprogrammet I998-200I.

St. meld. nr. 29 (2000-200I) Retningslinjer for den økonomiske politikken.

St. meld. nr. 30 (2000-200I) Langtidsprogrammet 2002-2005.

St. meld. nr. I2 (2004-2005) Pensjonsreform - trygghet for pensjonene.

Statistisk sentralbyrå (2015) Arbeidskraftundersøkinga, sesongjusterte tal, april 20I5, nyhetsbrev 24 juni 2015 .

URL: https://www.ssb.no/arbeid-og-lonn/statistikker/akumnd/maaned/20I5-06-24 (22 september 2015)

Streeck, W. (2013) Köpt tid. Den demokratiska kapitalismens uppskjutna kris. Daidalos, Göteborg.

Sundén, A. (1998) "The Swedish NDC pension reform". Annals of Public and Cooperative Economics, vol. 69, $\mathrm{nr} 4$. DOI: http://dx.doi.org/IO.IIII/I467-8292.00095

Swank, D. (2002) Global capital, political institutions and policy change in developed welfare states. Cambridge University Press, Cambridge.

Tegnér, E. (1959 [1828]) Smärre samlade dikter. I. CWK Gleerups förlag, Lund.

Thelen, K. (2003) "How institutions evolve. Insights from comparative historical analysis". I: J. Mahoney \& D. Reuschemeyer (red.), Comparative historical analysis in the social sciences. Cambridge University Press, Cambridge.

Tusen och en natt. Aladdin och den underbara lampan och andra sagor (2012) Bokförlaget Tranan, Stockholm.

Valebrokk, K. (2004) "Et land av melk og honning”. I: T. Bull \& H. Norvik (red.), Norge. Portrett av en nasjon. Dinamo forlag, Lysaker.

Watson, M. \& Hay, C. (2003) "The discourse of globalisation and the logic of no alternative. Rendering the contingent necessary in the political economy of New Labour". Policy \& Politics, vol. 3I, nr 3. DoI: http://dx.doi.org/IO.1332/030557303322034956

Weaver, R. K. (1986) "The politics of blame avoidance”. Journal of Public Policy, vol. 6, nr 4. DOI: http://dx.doi.org/Io.IOI7/SoI438I4Xoooo4219

Weaver, R. K. (2006) "Government institutions, policy cartels, and policy-change". I: I. Shapiro, S. Skowronek \& D. Galvin (red.), Rethinking political institutions. The art of the state. New York University Press, New York.

West Pedersen, A. (2004) "Halvhjertet kopi av brutal original. En sammenligning av Pensjonskommisjonens forslag og det nye svenske pensjonssystemet". Tidsskrift for Velferdsforskning, vol. 7, nr 3. 
West Pedersen, A. (2005) Two technical choices with critical implications. Issues in Scandinavian pension reform. Norsk institutt for forskning om oppvekst, velferd og aldring, Oslo.

West Pedersen, A. (2009) "Fra konkurranse til kompromiss. En sammenlignende studie av to norske pensjonsreformer". I: A.-H. Bay, A. West Pedersen \& J. Saglie (red.), Når velferd blir politikk. Partier, organisasjoner og opinion. Abstrakt forlag, Oslo.

Whitehouse, E., D’Addio, A., Chomik, R. \& Reilly, A. (2009) "The future of pensions and retirement income. Two decades of pension reform. What has been achieved and what remains to be done?" The Geneva Papers on Risk and Insurance - Issues and Practice, vol. 34 .

DoI: http://dx.doi.org/Io.I057/gpp.2009.30

Vägval för premiepensionen (2013) Ds 2013:35, Finansdepartementet, Stockholm.

Världsbanken (1994) Averting the old age crisis. Policies to protect the old and promote growth. Oxford University Press \& Världsbanken, Oxford.

Åmark, K. (2005) Hundra år av välfärdspolitik. Välfärdsstatens framväxt $i$ Norge och Sverige. Boréa, Umeå.

Östberg, K. \& Andersson, J. (2013) Sveriges historia. I965-2012. Norstedts, Stockholm.

Øverbye, E. (200I) "Norge. Mitt emellan den svenska och den danska pensionsmodellen". I: J. Palme (red.), Privata och offentliga pensionsreformer i norden. Slut på folkpensionsmodellen? Pensionsforum, Stockholm. 

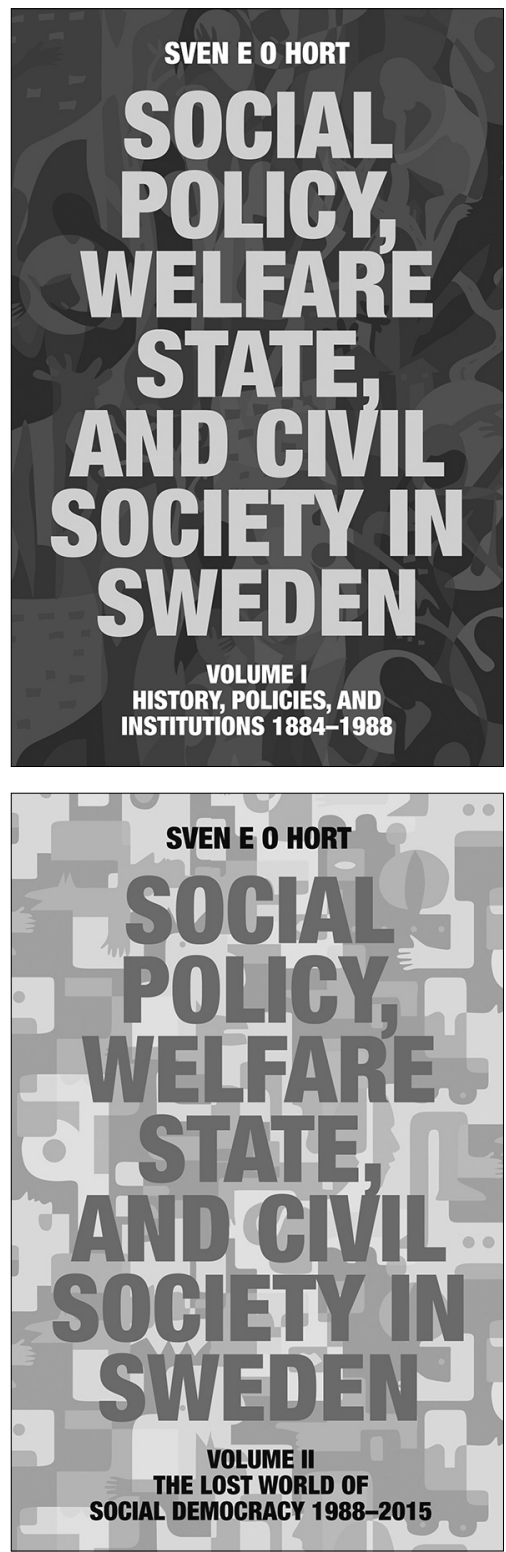

\section{SOCIAL POLICY, WELFARE STATE, AND CIVIL SOCIETY IN SWEDEN}

\author{
VOLUME | \& ||
}

\section{SVEN E 0 HORT}

Den tredje, aktualiserade och utökade upplagan i två volymer av Sven Horts inflytelserika studie av den svenska välfärdsstaten. Verket gavs ursprungligen ut 1990, under författarens dåvarande namn Sven E Olsson, som Social Policy and Welfare State in Sweden. Med den nya upplagan har boken utökats med en nyskriven volym II som handlar om de nya utmaningar som välfärdsstaten mött efter 1988 . Särskilt fokus ligger på hur den en gång så berömda svenska välfärdsstaten samtidigt nedrustats och omdanats under perioden, och utvecklingen jämförs med den i Danmark, Norge och Finland.

\section{Arkiv förlag 20I4, 2 flexband, 346 respektive 208 sidor}

